\title{
Algal Conditions and the \\ Potential for Future Algal Problems in the Willamette River, Oregon
}

River-Quality Assessment of the Willamette River Basin, Oregon

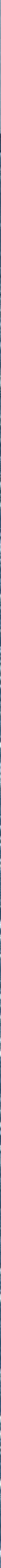




\section{Algal Conditions and the Potential for Future Algal Problems in the Willamette River, Oregon}

By David A. Rickert, Richard R. Petersen, Stuart W. McKenzie, Walter G. Hines, and Stephen A. Wille

GEOLOGICAL SURVEY CIRCULAR 715-G 


\section{United States Department of the Interior}

THOMAS S. KLEPPE, Secretary

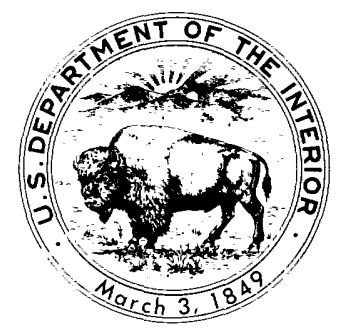

\section{Geological Survey}

V. E. McKelvey, Director

Library of Congress Cataloging in Publication Data

Rickert, David A., 1940-

Algal conditions and the potential for future algal problems in the Willamette River, Oregon.

(River-quality assessment of the Willamette River Basin, Oregon)

(Geological Survey Circular 715-G)

Bibliography: p. 35-36.

Supt. of Docs.: I $19.4 / 2: 715-\mathrm{G}$

1. Freshwater algae-Oregon-Willamette River. 2. Eutrophication-Oregon-Willamette River.

3. Water quality-Oregon-Willamette River. 4. Willamette River. I. Rickert, David A.,

1940- II. Series. III. Series: United States Geological Survey Circular 715-G.

QE75.C5 no. 715-G[QK571.5.07] 557.3'08s[589.39'297953] 76-608336 


\section{FOREWORD}

The American public has identified the enhancement and protection of river quality as an important national goal, and recent laws have given this commitment considerable force. As a consequence, a considerable investment has been made in the past few years to improve the quality of the Nation's rivers. Further improvements will require substantial expenditures and the consumption of large amounts of energy. For these reasons, it is important that alternative plans for river-quality management be scientifically assessed in terms of their relative ability to produce environmental benefits. To aid this endeavor, this circular series presents a case history of an intensive river-quality assessment in the Willamette River basin, Oregon.

The series examines approaches to and results of critical aspects of riverquality assessment. The first several circulars describe approaches for providing technically sound, timely information for river-basin planning and management. Specific topics include practical approaches to mathematical modeling, analysis of river hydrology, analysis of earth resources-river quality relations, and development of data-collection programs for assessing specific problems. The later circulars describe the application of approaches to existing or potential river-quality problems in the Willamette River basin. Specific topics include maintenance of high-level dissolved oxygen in the river, effects of reservoir release patterns on downstream river quality, algal growth potential, distribution of toxic metals, and the significance of erosion potential to proposed future land and water uses.

Each circular is the product of a study devoted to developing resource information for general use. The circulars are written to be informative and useful to informed laymen, resource planners, and resource scientists. This design stems from the recognition that the ultimate success of river-quality assessment depends on the clarity and utility of approaches and results as well as their basic scientific validity.

Individual circulars will be published in an alphabetical sequence in the Geological Survey Circular 715 series entitled "River-Quality Assessment of the Willamette River Basin, Oregon."

J. S. Cragwall, Jr.

Chief Hydrologist 
Cover: Willamette River as it winds through Portland, Oregon. Photograph taken by Hugh Ackroyd. 


\section{CONTENTS}

Abstract

Introduction

The Willamette River basin

Willamette River morphology

Upstream Reach

Newberg Pool

Tidal Reach

Reservoirs .

Methods of assessment

Descriptive assessment

The data program

Reconnaissance studies ....................

Intensive studies

Field and laboratory procedures

Results

Nutrients

Nitrogen and phosphorus loadings

Concentrations of nitrogen, phosphorus, silica

Temperature

Light penetration

Algal populations

General characteristics

\begin{tabular}{|c|c|c|}
\hline Page & & $\mathrm{Pa}$ \\
\hline G1 & Results-Continued & \\
\hline 1 & Algal populations-Continued & \\
\hline 1 & Assemblages & G17 \\
\hline 2 & A downstream traverse & 17 \\
\hline 2 & Comparison with historical data & 21 \\
\hline 4 & Primary productivity & 21 \\
\hline 4 & Light- and dark-bottle method & 21 \\
\hline 4 & Oxygen-curve method & 24 \\
\hline 4 & Comparison with other rivers & 24 \\
\hline 5 & Effect of nutrient additions & 24 \\
\hline 5 & Discussion & 24 \\
\hline 5 & Low-temperature limitation & 25 \\
\hline 5 & Light limitation & 25 \\
\hline 6 & Trace-nutrient limitation & 28 \\
\hline 6 & rient limitation & 28 \\
\hline 7 & Carbon & 28 \\
\hline 7 & Nitrogen and phosphorus & 28 \\
\hline 7 & Detention-time limitation & 29 \\
\hline 7 & $\begin{array}{l}\text { Lonceptual model of factors controlling } \\
\text { land the nature of algae }\end{array}$ & 30 \\
\hline 10 & Planning implications & 32 \\
\hline 11 & Acknowledgments & 33 \\
\hline 12 & Glossary - & 33 \\
\hline 12 & References cited & 35 \\
\hline
\end{tabular}

\section{ILLUSTRATIONS}

Page

\section{7}

21

21

24

24

24

24

25

25

28

28

FIGURE 1. Map and diagram representing the Willamette River, Oreg., showing distinctive hydrologic reaches and elevation profile

2-5. Graphs showing:

2. Typical channel cross sections of the Willamette River, at concurrent low-flow conditions

3. Time and spatial variations of dissolved orthophosphate phosphorus concentrations in the Willamette River, July-November 1973

4. Time and spatial variations of dissolved major nutrient concentrations in the Willamette River, June-November 1974

5. Time and spatial variations of dissolved silica concentrations in the Willamette River, JuneNovember 1974

6. Hydrograph of the Willamette River at Portland, 1974

7. Graph showing daily water temperatures at mile 7.0, Willamette River, May-September $1974 \ldots \ldots$

8. Graph showing diel-dissolved oxygen curves, light penetration, and elevation profiles for summer low-flow conditions of the Willamette River, mid-July 1973

9-15. Graphs showing abundance of selected algae, by station and time, in the Willamette River, June-September 1974:

9. Stephanodiscus hantzschii

10. Achnanthes minutissima

11. Melosira distans

12. Cymbella ventricosa

13. Asterionella formosa

14. Green algae -... 16

15. Anabaena spp 
16. Graph showing abundance of selected algae in the Willamette River, August 7, 1973

17. Diagram showing summary of the time and spatial distribution of algal populations in the Willamette River, May-September 1974

18. Graphs showing abundance of selected algae in the Willamette River and certain tributaries, August 5-7, 1974

19. Diagram showing time variation of algal types in the Willamette River, at mile 8.1, April-Soptember 1963

20. Diagram showing time variation of algal types in the Willamette River, at mile 7.0, June-Saptember 1974

21. Diagram showing relative abundance of diatoms and blue-green algae in net plankton of the Tualatin River at Farmington, Oreg., March-August 1973

22-25. Graphs showing:

22. The vertical distribution of primary gross productivities in the lower Willamette River, at selected times during summer, 1974

23. Effect of nutrient additions on algal productivity of Willamette River samples, mile 7.0, July 24,

24. Effect of nutrient additions on algal productivity of Willamette River samples, mile 12.8, August 8, 1974 -

25. Effect of nutrient additions on algal productivity of Willamette River samples, mile 12.8, Saptember 17,1974

26. Conceptual diagram relating algal biomass and dominant algal types to water-detention time and light penetration

\section{TABLES}

TABLE 1. Selected physical characteristics of the main stem Willamette River, Oreg

2. Estimated loading of dissolved major nutrients to the Willamette River during summer low-flow conditions 7

3. Estimated gross primary productivity at the surface of different rivers

4. Algal counts at mile 7.0, Willamette River, Oreg., during 1973

5. Algal counts at mile 7.0, Willamette River, Oreg., during 1974

\section{CONVERSION FACTORS} shown only to the number of significant figures consistent with the values for the English units]

English
$\mathrm{ft}$ (feet)
$\mathrm{ft} / \mathrm{s}$ (feet per second)
$\mathrm{ft} / \mathrm{mi}$ ( feet per mile)
$\mathrm{ft}^{3} / \mathrm{s}$ (cubic feet per second)
acre-ft (acre-feet)
$\mathrm{mi}$ (miles)
$\mathrm{mi}^{2}$ (square miles)
$\mathrm{lb} / \mathrm{d}$ (pounds per day)

English

$\mathrm{ft} / \mathrm{s}$ (feet per second)

$\mathrm{ft} / \mathrm{mi}$ (feet per mile)

$\mathrm{ft}^{3} / \mathrm{s}$ (cubic feet per second)

mi (miles)

$\mathrm{lb} / \mathrm{d}$ (pounds per day)

Multiply by
$3.048 \times 10^{-1}$
$3.048 \times 10^{-1}$
$1.894 \times 10^{-1}$
$2.832 \times 10^{-2}$
$1.233 \times 10^{-3}$
1.609
2.590
$4.536 \times 10^{-1}$

Metric (SI)

$\mathrm{m}$ (metres)

$\mathrm{m} / \mathrm{s}$ (metres per second)

$\mathrm{m} / \mathrm{km}$ (metres per kilometre)

$\mathrm{m}^{3 / \mathrm{s}}$ (cubic metres per second)

$\mathrm{hm}^{3}$ (cubic hectometres)

$\mathrm{km}$ (kilometres)

$\mathrm{km}^{2}$ (square kilometres)

$\mathrm{kg} / \mathrm{d}$ (kilograms per day) 


\title{
Algal Conditions and the Potential for Future Algal Problems in the Willamette River, Oregon
}

\author{
David A. Rickert, Richard R. Petersen, Stuart W. McKenzie, Walter G. Hines, and Stephen A. Wille
}

\begin{abstract}
ABSTRAC:T
The summertime concentrations of nitrogen and phosphorus in the Willamette River exceed the generally accepted threshold levels for excessive algal growth. Nevertheless, the primary productivity is low for a river, and the algal community is dominated by diatoms. Bioassay tests with various additions of nitrogen and phosphorus, minor nutrients, and municipal and industrial effluents showed no marked increase in algal production over control samples. Results suggest that algal growth in the Willamette is maintained in a state of healthy balance by short detention times of water and possibly also by low light availability resulting from turbidity.
\end{abstract}

\section{INTRODUCTION}

In 1972, the Willamette River, Oreg., achieved the status of being the largest river in the United States for which all known waste-water sources (municipal and industrial) received secondary treatment. Although this action sharply decreased the waste loading of carbon to the river, the loading of nitrogen and phosphorus remained high because these nutrients are inefficiently removed by secondary-treatment processes. As a result, summertime concentrations of carbon in the Willamette are fairly low, but the concentrations of nitrogen and phosphorus are high.

Despite the high nitrogen and phosphorus concentrations, excessive growths of algae (see "Glossary" for definition of technical terms) have not been observed. The reason might be any one of several, including trace-metal limitations, unfavorable water temperatures, high summertime turbidities, or short water-detention times. On the other hand, the environment in the Willamette River could possibly be approaching a condition in which large, problem-causing growths of algae might begin to occur. Recent work in the Upper Potomac Estuary suggests that the initiation of secondary treatment may cause ecological shifts in receiving waters and actually stimulate the growth of nuisance blue-green algae (Jaworski and others, 1972).

This circular characterizes the present algal populations of the Willamette River and attempts to determine which environmental factors are the major controls on algal growth and froduction. The report also describes the implication of these findings to the planning and management of future river quality.

\section{THE WILLAMETTE RIVER BASIN}

The Willamette River basin, a watershed of nearly $11,500 \mathrm{mi}^{2}\left(29,800 \mathrm{~km}^{2}\right)$ (fig. 1), is located in northwestern Oregon between the Cascade and Coast Ranges. Within the basin are the State's three largest cities, Portland, Salem, and Eugene, and approximately 1.4 million people, representing 70 percent of the State's population (1970 census). The Willamette River basin supports an economy based on timber, agriculture, industry, and recreation and contains extensive fish and wildlife habitats.

The basin is roughly rectangular, with a north-south length of about $150 \mathrm{mi}(240 \mathrm{~km})$ and an east-west width of $75 \mathrm{mi}(120 \mathrm{~km})$. Elevations vary from less than $10 \mathrm{ft}(3 \mathrm{~m})$ near the mouth of the Willamette River, to $450 \mathrm{ft}(140 \mathrm{~m})$ on the valley floor near Eugene, to more than $10,000 \mathrm{ft}$ $(3,000 \mathrm{~m})$ in the Cascade Range. The Coast Range varies in average elevation from 1,000 to $2,000 \mathrm{ft}$ $(300$ to $600 \mathrm{~m}$ ) but includes peaks higher than $4,000 \mathrm{ft}(1,200 \mathrm{~m})$.

The slopes and foothills of the Cascade Range account for more than 60 percent of the basin area. About 62 percent of the basin is timberland, located largely in the tributary basins (Gleeson, 1972). Approximately 33 percent of the area is farmland, and the remaining 5 percent is urbanized and in other uses. 


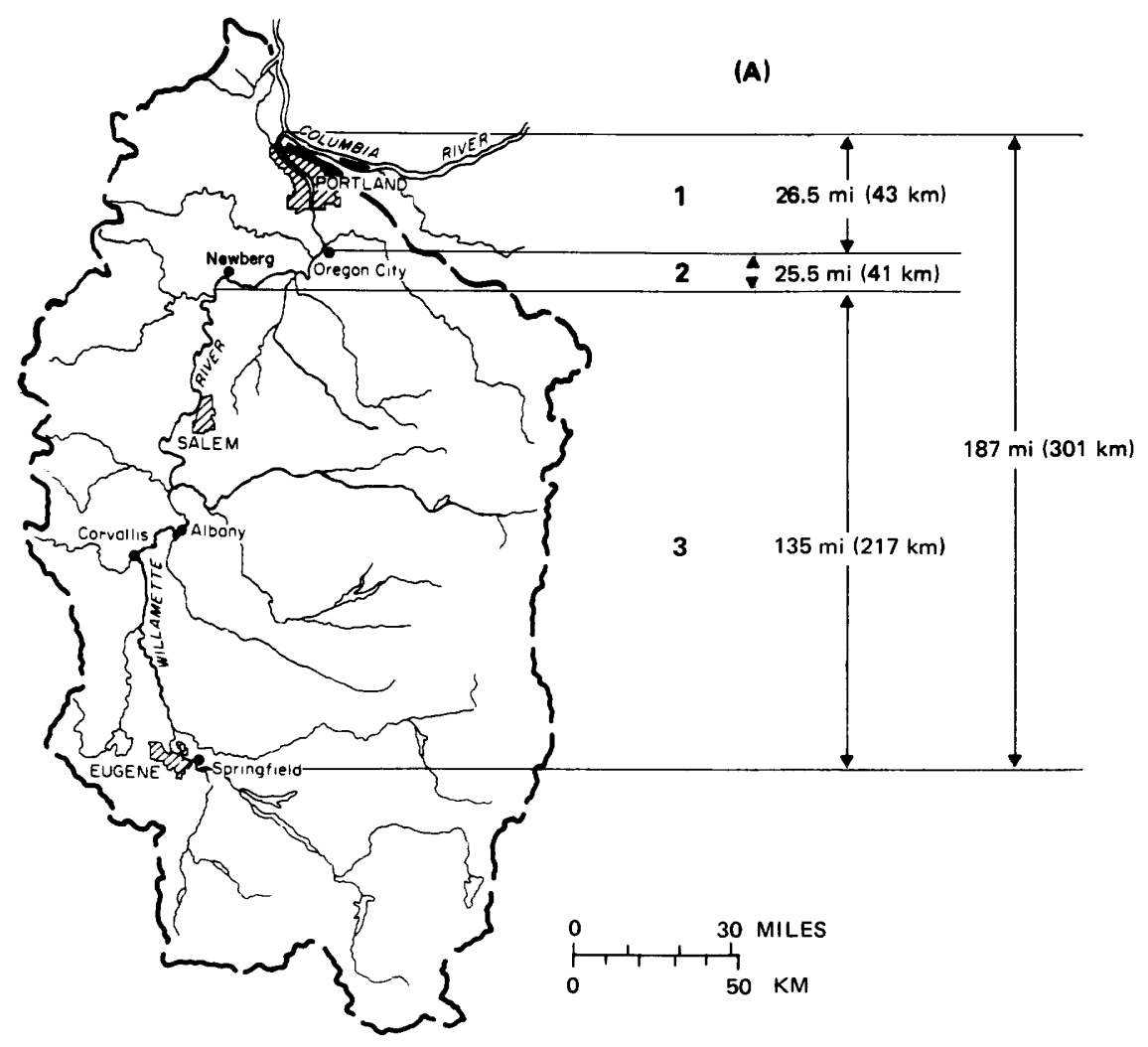

(B)

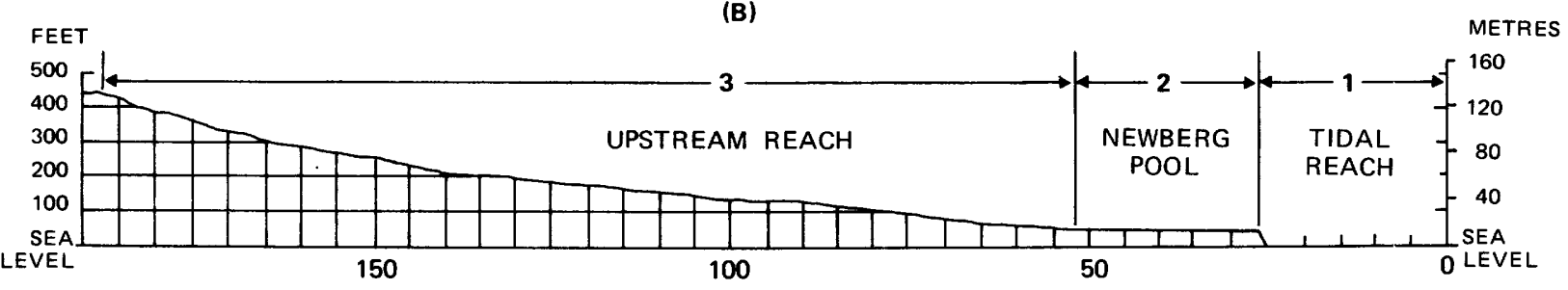

DISTANCE, IN RIVER MILES ABOVE MOUTH

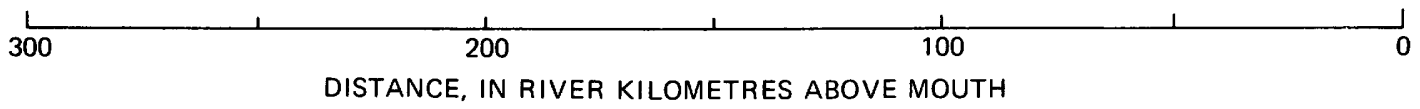

FIgURE 1.-Willamette River, Oreg. (A) Distinctive hydrologic reaches. (B) Elevation profile.

WILLAMETTE RIVER MORPHOLOGY

The main stem Willamette River forms at the confluence of its Coast and Middle Forks near Eugene and flows northward for $187 \mathrm{mi}(301 \mathrm{~km})$ through the $3,500-\mathrm{mi}^{2}\left(9,100-\mathrm{km}^{2}\right)$ Willamette Valley floor. The river bed drops from an altitude of $435 \mathrm{ft}(132 \mathrm{~m})$ at Eugene to slightly below mean sea level at Portland (fig. 1). The Willamette empties into the Columbia River at a point which is $99 \mathrm{mi}(160 \mathrm{~km})$ from the Pacific Ocean.
The Willamette River comprises three distinctive reaches whose physical characteristics govern the hydraulics of flow and therefors the rates and patterns of deposition, channel scour, and biological activity. Pertinent data for each of the three reaches are included in figures 1 and 2 and in table 1.

\section{UPSTREAM REACH}

The Upstream Reach, extending for $135 \mathrm{mi}$ $(217 \mathrm{~km})$ from Eugene to above Newberg, is characterized by a meandering channel. The river 

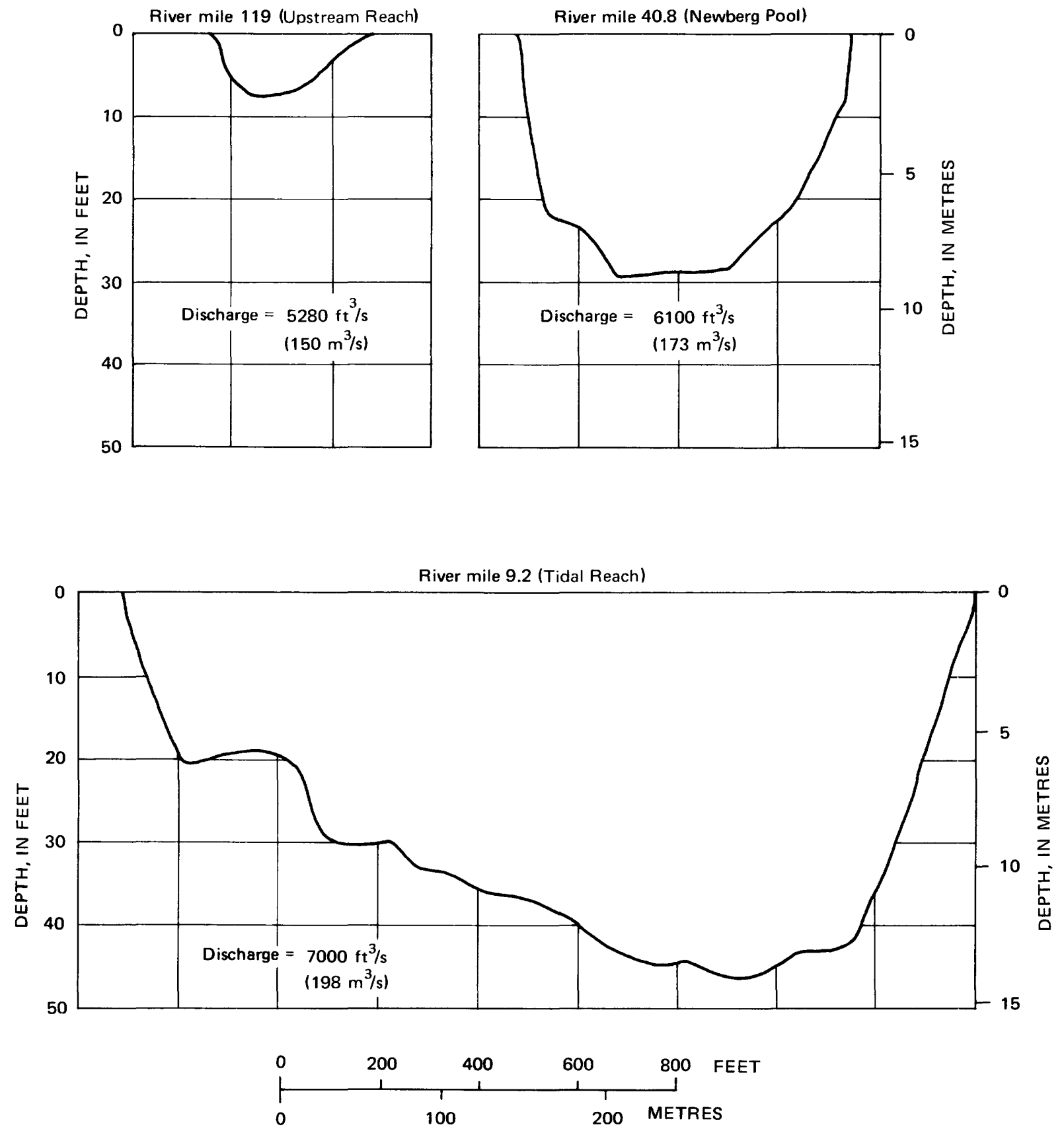

FiguRE 2.-Typical channel cross sections of the Willamette River, at concurrent low-flow conditions. The large downstream increases in width and depth greatly affect the hydraulics of flow and, thereby, partly determine tl ? reach-byreach potential for biological problems.

is shallow (table 1), and the bed is composed almost entirely of cobbles and gravel which during summer are covered with biological growth.

Although the U. S. Army Corps of Engineers has straightened the course of the river in this reach considerably, there are still numerous meanders, islands, and side channels. At low flow, gravel bars are visible, and, in some places, the river is so shallow that small pleasure boats occasionally run aground.

During low-flow conditions, average stream velocity in the Upstream Reach is more than 7 times that of either of the two downstream reaches (table 1). During floods, velocities are sufficiently 
TABLE 1.-Selected physical characteristics of the main stem Willamette River, Oreg.

[Characteristics refer to summer low-flow conditions of $6 \times 10^{3} \mathrm{ft}^{3 / \mathrm{s}}$ at Salem]

\begin{tabular}{|c|c|c|c|c|c|c|}
\hline $\begin{array}{l}\text { Reach } \\
\text { Isee fig. } 11\end{array}$ & $\begin{array}{l}\text { Length } \\
\text { Imil }\end{array}$ & $\begin{array}{l}\text { Approximate } \\
\text { bed slope } \\
\text { (ft/mil }\end{array}$ & Bed material & $\begin{array}{c}\text { Representative } \\
\text { midchannel } \\
\text { water depth } \\
\text { (ft) }\end{array}$ & $\begin{array}{l}\text { Average } \\
\text { velocity } \\
\text { |ft/s }\end{array}$ & $\begin{array}{c}\text { Approsimate } \\
\text { traveltime } \\
\text { in reach } \\
\text { (days }\end{array}$ \\
\hline Tidal Reach. & 26.5 & $<0.1$ & $\begin{array}{l}\text { Intermixed clay, sand, and } \\
\text { gravel }\end{array}$ & 40 & ${ }^{1} 0.16$ & 10.0 \\
\hline Newberg Pool. (2) & 25.5 & .12 & $\begin{array}{l}\text { Intermixed clay, sand, and } \\
\text { gravel with some cobbles. }\end{array}$ & 25 & ${ }^{1} .40$ & 3.9 \\
\hline Upstream Reach. (3) & 135 & 2.8 & Mostly cobbles and gravel & 7 & 22.9 & 2.8 \\
\hline
\end{tabular}

'Calculated by volume displacement method using channel cross-sectional data

'Calculated from dye study conducted by U.S. Geological Survey i Harris, 1968:

high to transport large quantities of cobbles and gravel as bedload. Morphologically, this upstream section of the Willamette is an "eroding" reach.

\section{NEWBERG POOL}

The Newberg Pool extends from just above Newberg to the Willamette Falls, a distance of $25.5 \mathrm{mi}(41.0 \mathrm{~km}$ ). The pool is deep (fig. 2), slowmoving, and can be characterized hydraulically as a large stilling basin behind a weir (Willamette Falls). The pool is a depositional reach, as evidenced by the elevation profile (fig. 1), low velocity, and the presence of fine bottom sediments.

\section{TIDAL. REACH}

The lower $26.5 \mathrm{mi}(42.6 \mathrm{~km})$ of the river is a deep, slow-moving reach affected by tides and, during spring and early summer, by backwater from the Columbia River (Velz, 1961). The Tidal Reach is extensively dredged to maintain a $40-\mathrm{ft}$ (12-m) deep navigation channel (fig. 2) from the mouth to about river mile (RM) 14 . The subreach between RM's 5 and 14 is a busy shipping corridor known locally as Portland Harbor.

During the summer low-flow period, net downstream movement is slow, but tidal effects cause flow reversals twice daily and large changes in velocity. Low-flow hydraulics are most complex in the lower $10 \mathrm{mi}(16 \mathrm{~km})$ (fig. 2) where, depending on hourly changes in tide- and river-stage conditions, Willamette River water may move downstream or Columbia River water may move upstream. Columbia River water has a slightly higher concentration of dissolved solids and is commonly several degrees cooler than Willamette water. Columbia water is, therefore, denser than Willamette water and during part of each day (during low flows) moves upstream as a distinct bottom wedge to the vicinity of the St. Johns Bridge (RM 6). The subsequent downstream movement of water is very complex. Depending on slight variations in tide and relative flows in the Willamette and the Columbia, the dcwnstream discharge may be out the mouth of the W'illamette, through Multnomah Channel, or a combination of the two.

Owing to morphological characteristics and hydraulic conditions, the subreach between RM's 10 and 3 is the primary depositional crea of the Willamette River system.

\section{RESERVOIRS}

There are 11 major reservoirs in the Willamette River basin, with a combired usable capacity of nearly 1.9 million acre-ft $\left(2,300 \mathrm{hm}^{3}\right)$. The reservoirs are designed for multipurpose use, but their primary legal function is the maintenance during summer of a minimum navigable depth in the Willamette River (Willam ette Basin Task Force, 1969). The required minimum flow for navigation is $6,000 \mathrm{ft}^{3} / \mathrm{s}\left(170 \mathrm{~m}^{3} / \mathrm{s}\right)$ at Salem. Other uses of the reservoirs and reservoir water include power generation, onsite recreation, flood protection, maintenance of adequate streamflow for anadromous fish propagation, irrigation, and flow augmentation for water-quality enhancement. The last use is not explicitly planned but occurs as a result of summertime releases made for the other purposes.

\section{METHODS OF ASSESSMENT}

Concern about the potential for algal problems led to a search for a suitable assessment method. An applied eutrophication model would have been ideal. At present, however, the complex eutrophication process is so poorly understood (Rickert and others, 1975a) that it is virtually impossible to develop applied models capable of quantitative predictions (McGauhey, 1974). Certainly, many years of fieldwork would the required to obtain data adequate to model the sources, sinks, and transport mechanisms of algal nutri- 
ents. Even more data would be necessary to quantify the relationship of algal growth to nutrient availability and to other environmental factors. These considerations indicated that it would be virtually impossible to formulate, calibrate, and verify a practical eutrophication model within the $2 \frac{1}{2}$-year time span of the study.

Instead of attempting to formulate a predictive mathematical model, a qualitative descriptive study was designed to provide insight into the potential for nuisance algal growth.

\section{DESCRIPTIVE ASSESSMENT}

Many river-quality problems exist that presently cannot be assessed through modeling, mapping, or the use of other specific methods. However, resource-planning information can be obtained for most of these problems through descriptive assessment. Descriptive assessment is basic to all other methods because it is the fundamental basis of scientific endeavor.

As applied in the algal study, descriptive assessment embodied problem definition, devising of hypotheses, collection and analysis of data, and exclusion of disproven hypotheses. For some specific problems, the cycle was repeated several times to refine the remaining possibilities. The final results are qualitative, because they provide no numerical predictions, but rather a general knowledge of the ways in which environmental and cultural factors combine to control riverquality phenomena.

The working hypotheses for this algal study were:

1. Nuisance algal growths are prevented by low water temperatures.

2. Nuisance algal growths are prevented by high summertime turbidities.

3. Nuisance algal growths are prevented by a scarcity of certain trace nutrients.

4. Nuisance algal growths will develop provided the loading of major nutrients to the Willamette remains constant or increases and loading ratios remain in the present proportion.

5. Nuisance algal growths are prevented by short detention times of water in the Willamette.

The remainder of this paper is devoted primarily to an examination of these hypotheses to determine which best explain observed algal conditions. The following sections on data programs and results are intended for readers interested in the technical aspects of the study. The nontechnical reader may wish to progress cirectly to the "Discussion."

\section{THE DATA PROGRAM}

Data to assess the working hypotheses were obtained through (1) analysis of existing data, (2) a reconnaissance-level study, and (3) an intensive field study.

\section{UISE OF EXISTING DATA}

Available data on hydrology (fig. 1; table 1) were analyzed to determine which reaches of the river are most susceptible to possible algal problems. Conditions of high temperature and slowmoving, slowly mixing water would seem to be most favorable to the nuisance forms of green and blue-green algae. Thus, should nuisance algal growths develop in the river, they would probably occur in the Tidal Reach and the Newkerg Pool.

Existing water-quality data were examined with regard to (1) nutrient loading, (2) nutrient concentrations in river water, (3) the types and numbers of algae, and (4) physical factors such as temperature and light availability. The data provided a good idea of what to expect for tle loading and, as previously noted, for the river concentrations of carbon, nitrogen, and phosphorus. No information was found on the loading and availability of trace algal nutrients.

Excellent temperature data were available, but the sparse data that did exist on algal species, algal quantities, and light penetration were from the mid-1960's when the river still received some untreated and primary treated waste waters. The relevance of the data to 1973 conditions was questionable, so a reconnaissance algal-monitoring study was immediately devised.

\section{RECONNAISSANCE STLDIES}

The reconnaissance-level work consisted of:

1. A plankton-monitoring network of five stations with three in the Tidal Reach (RM's $7.0,12.8$, and 21.2) and two in the Newberg Pool (RM's 35.0 and 50.0). The stations were sampled at least once every 2 weeks from June through September of 1973 and 1974 and occasionally during other months of both years. Water samples were collected for enumeration of suspended algae and the determination of plant nutrients. In situ 
measurements were made of dissolved oxygen ( $\mathrm{DO}), \mathrm{pH}$, temperature, and light penetration.

2. Periodic analysis of waste-water effluents and tributary inflows to determine the river loading of major algal nutrients.

Information obtained from this reconnaissance was used to design a series of intensive studies.

\section{INTENSIVE STUDIES}

The intensive studies were designed to document the chemical and physical conditions associated with the onset of peak algal growth and the impact of this growth on river quality. The work included the following elements, which were done simultaneously:

1. Intensive sampling at the five stations included in the reconnaissance network. Samples for analysis of algae and nutrients were collected at least once per day. Incident light and light penetration were measured several times a day, whereas temperature, DO, and $\mathrm{pH}$ were monitored continuously.

2. Algal production-respiration determinations using the light- and dark-bottle DO and carbon-14 techniques (Slack and others, 1973). These were made at several depths at the Tidal Reach stations on six different occasions.

3. Enrichment bioassays conducted at the same stations and depths, and by the same techniques, as the basic production-respiration tests. Treatments included enrichment with nitrogen and phosphorus (separately and in combination), mixtures of trace nutrients (see Environmental Protection Agency, 1971), domestic sewage effluents, and pulpand paper-mill effluents. These tests were run on three occasions.

\section{FIELD AND LABORATORY PROCEDURES}

Water samples for nutrient and algal analysis consisted of several subsamples taken at regular intervals across the river and vertically integrated to the approximate depth of the euphotic zone. The collections were made with a USDH-59 depthintegrating suspended-sediment sampler.

Each composite euphotic-zone sample was immediately proportioned and prepared for various analyses. Aliquots for determination of suspended algae were prepared by the membrane- filter concentration technique (American Public Health Association and others, 1971); a sample size of $100 \mathrm{ml}$ (millilitres) was usually suitable. Aliquots for analysis of orthophosphate and silica were filtered immediately after collection using $0.45-\mu \mathrm{m}$ pore-size filters (Millipore-type HA). ${ }^{1}$ The orthophosphate was then extracted with isobutanol (Shapiro, 1973a). Aliquots for total nitrogen, total phosphorus, ammonia, nitrite, and nitrate were transferred to 1-quart folyethylene bottles and kept on ice for return to the laboratory.

Light intensity was measured at 1-m intervals using a Whitney Model LMD-8A underwater light meter without color filters. Temperature and DO were routinely determined with a YSI Model 54 Oxygen Meter. On several occasions, temperature, $\mathrm{DO}$, and $\mathrm{pH}$ were monitored continuously for several days with a Martek Mark II Water Quality Analyzer.

Primary productivity was measure on several occasions by the DO light- and dark-bottle method and once by the carbon-14. light- and dark-bottle method (Slack and others, 1973). Bioassay experiments to assess the possibility of nutrient limitations were conducted according to Vollenweider (1969).

Total nitrogen and total phosphorus were determined by standard methods of the U.S. Geological Survey (Brown and others, 1970) and dissolved silica by the reactive-silicate method (as the yellow complex) (Golterman and Clymo, 1971). Nitrate was determined by the brucine method and ammonia by Nesslerization following distillation (American Public Health Association and others, 1971); both analyses wer? run within 24 hours of sample collection. On several occasions, alkalinity was measured in the field by the method in Brown, Skougstad, ard Fishman (1970). The alkalinity results were used in conjunction with $\mathrm{pH}$ data to estimate total carbonate carbon from the nomograph of Deffeyes (1965).

The membrane filters for analysis of algae were examined with a Zeiss standard phase contrast microscope at a magnification of $1,000 \times$ and a circular counting field $0.15 \mathrm{~mm}$ (millimetre) in diameter. The reported counts were calculated from data on the number of times each species, genus, or group was observed in a standard

${ }^{1}$ Use of names of commercial products is for identification only and does not imply endorsement by the U.S. Geological Survey. 
number of fields (American Public Health Association and others, 1971). Most species occurred and were scored as single cells. Multicellular species were scored as colonies up to a maximum length of $0.15 \mathrm{~mm}$ (corresponding to the counting field diameter). Thus, the counts represent individual cells, or colonies, depending on the species. Consequently, counts are consistent within a species and over time but cannot be directly compared from one species to another without taking average cell numbers" into consideration.

\section{RESULTS}

\section{NUTRIENTS}

\section{NITROGEN AND PHOSPHORUS LOADINGS}

Data from several sources have been collated to estimate the daily summertime loading of inorganic (ammonia, nitrite, and nitrate) nitrogen and orthophosphate phosphorus (table 2). Most of the data were collected during July and early August 1974 for purposes of studying nitrification and verifying a DO model. Data for small sewage-treatment plants and small tributaries were provided by the Oregon Department of Environmental Quality (DEQ).

The land-runoff category (table 2) was calculated by summing the nonpoint-source contributions of individual tributaries (see Hines and others, 1977). These contributions were calculated for each tributary by subtracting measured point-source loadings of nitrogen and phosphorus from computed in-stream loads. To provide an internal check, stream-nutrient concentrations were measured above and below each major municipal and industrial discharge. On the Willamette main stem, the individual inputs from point and land-runoff sources were mathematically flow routed and at regular intervals comparisons were made between computed and measured in-river loads.

The estimates indicate that point sources contributed about 80 percent of the orthophosphorus and 70 percent of the inorganic nitrogen during the low-flow period. For orthophosphorus, municipal effluents contributed 66 percent and industrial effluents 14 percent of the point-source loading. In contrast, industrial discharges accounted for 55 percent and sewage-treatment plants for 14 percent of the point-source nitrogen. An undefined but localized source contributed 24 percent of the nitrogen between RM's 120 and 114 (vicinity of Albany, Oreg.). This source was in ad-
TABLE 2.-Estimated loading of dissolved major nutrients to the Willamette River during summer low-flow conditions ${ }^{1}$

\begin{tabular}{|c|c|c|c|c|}
\hline \multirow[b]{2}{*}{ Source } & \multicolumn{2}{|c|}{$\begin{array}{c}\text { Orthophosphate as } \\
\text { phosphorus }\end{array}$} & \multicolumn{2}{|c|}{$\begin{array}{l}\text { Amronia + nitrite }+ \\
\text { nitrate as nitrogen }\end{array}$} \\
\hline & $\mathrm{lb} / \mathrm{d}$ & Percent & $\mathrm{lb} / \mathrm{d}$ & Percent \\
\hline $\begin{array}{l}\text { Land runoff } \\
\text { Municipal effluents } \\
\text { Industrial effluents } \\
\text { Unknown'2 }\end{array}$ & $\begin{array}{r}900 \\
2,900 \\
600 \\
----\end{array}$ & $\begin{array}{l}20 \\
66 \\
14 \\
--\end{array}$ & $\begin{array}{r}3,300 \\
7,000 \\
28,000 \\
12,000\end{array}$ & $\begin{array}{r}7 \\
14 \\
55 \\
24\end{array}$ \\
\hline Total & 4,400 & 100 & 50,300 & 100 \\
\hline
\end{tabular}

1"Dissolved" means that samples were filtered $(0.45 \mu \mathrm{m}$ filter $)$ prior to analysis. Dissolved rather than total loadings are reported to reflect the loading of soluble "biologically available" nutrients. Duplicate analysis of selected whole water (unfiltered I samples showed slightly higher concentrations, but similar percentage filtered ' samples showed slightly highe
contributions from the histed sources.

contributions from the liste
2See text for explanation.

dition to the estimated input from Fourth Lake and was also evident in data collected between 1972 and 1975 by the Oregon DEQ. The resultant nitrogen loading has been categorized as unknown (table 2) because sufficient data were not collected to verify the source and the points of entry into the river. However, available information suggested that this nitrogen did not derive from normal land runoff and hence was a potentially controllable source.

"Controllable" sources thus contributed about 90 percent of the inorganic nitrogen and 80 percent of the orthophosphorus which entered the Willamette during the peak period of algal productivity. The noted comparison between flowrouted inputs and measured river loads indicated that bottom sediments did not contribute to the summertime in-river loads of dissolved nitrogen and phosphorus.

The high percentage of phosphorus from pointsource discharges compares closely with the reported values of 87 percent for the Potomac River basin and 73 percent for the Hudson River basin (Jaworski and Hetling, 1970). However, the estimated 90 percent point-source loading of nitrogen exceeds by a wide margin the comparative values of 63 percent for the Potomac and 51 percent for the Hudson. The difference results primarily from a relatively large industrial loading of ammonia in the Willamette River basin, together with the large unknown (but probably industrially related) source of nitrogen in the vicinity of Albany.

\section{CONCENTRATIONS OF NITROGEN PHOSPHORL'S, AND SILICA}

The concentrations of dissolved algal nutrients by station and over time are shown in figures 3,4 , and 5 .

During the 1973 and 1974 field seasons, the lowest determined concentration of orthophos- 

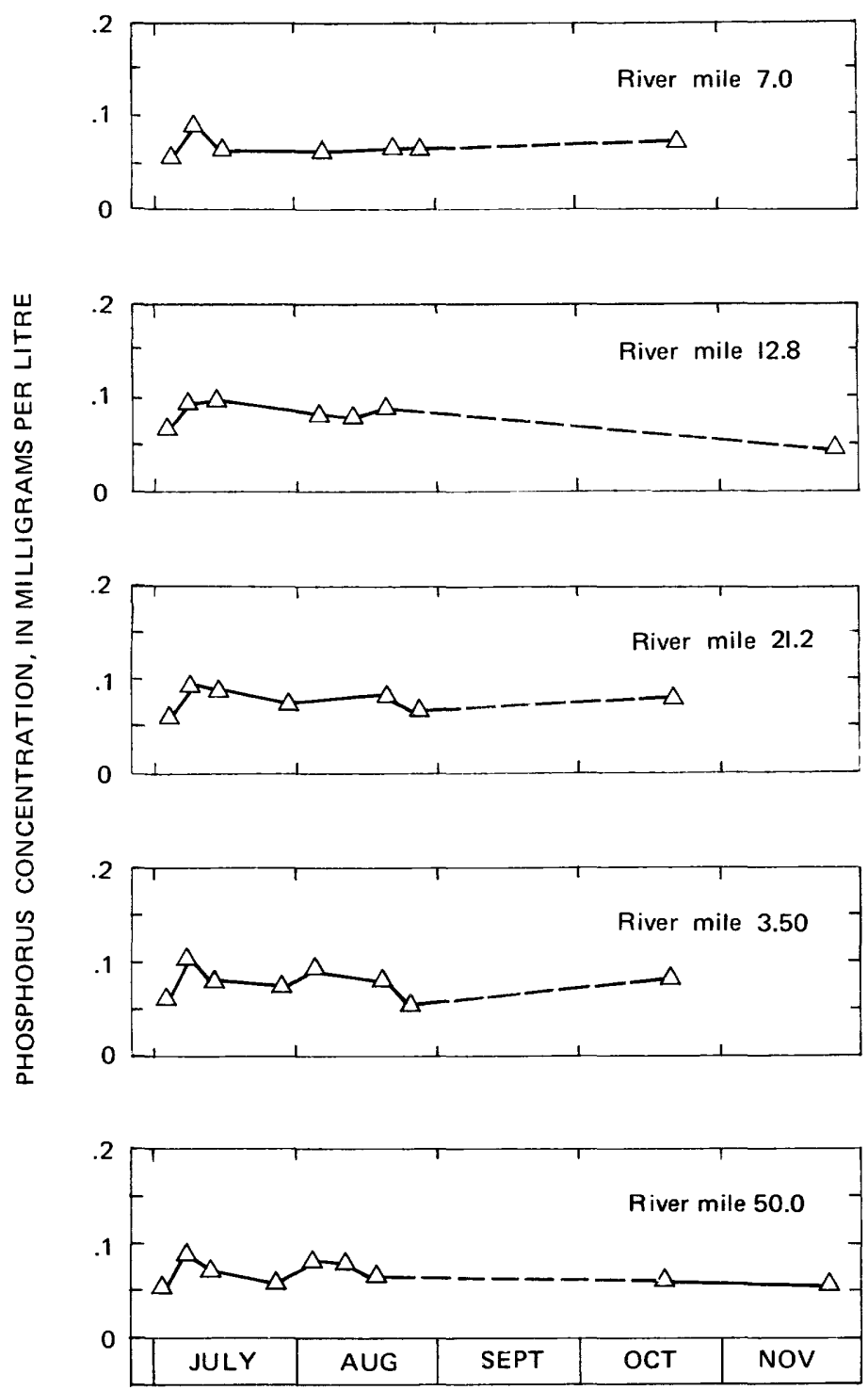

FIGURE 3.-Time and spatial variations of dissolved orthophosphate phosphorus concentrations in the Willamette River, July-November 1973.

phate phosphorus $\left(\mathrm{PO}_{4}-\mathrm{P}\right)$ was 0.035 milligrams per litre $(\mathrm{mg} / \mathrm{l})$ and the highest was $0.092 \mathrm{mg} / \mathrm{l}$. Most concentrations fell between 0.05 and 0.08 $\mathrm{mg} / \mathrm{l}$ (figs. 3, 4), a narrow range that is consistent with the limited range of streamflows under which most of the samples were collected. (See fig. 6.) Moreover, not only were the concentrations relatively stable, but they were at all times well above the concentrations of phosphorus observed in some highly productive natural waters (Schindler, 1971).
The combined concentrations of ammonia $\left(\mathrm{NH}_{4}-\mathrm{N}\right)$ nitrite $\left(\mathrm{NO}_{2}-\mathrm{N}\right)$ plus nitrate nitrogen $\left(\mathrm{NO}_{3}-\mathrm{N}\right.$ ) (range of $0.28-2.94 \mathrm{mg} / \mathrm{l}$ ) were considerably more variable than the phosphorus concentrations (fig. 4, 1974 data only) but were always quite high relative to theoretical algal rexuirements. The scales in figure 4 are adjusted so that nitrogen and phosphorus concentrations appear equal when the two are present in a molar ratio of $16 \mathrm{~N}: 1 \mathrm{P}$ (approximate ratio in algal cells) (Stumm and Morgan, 1970; Kramer and others, 1972). 


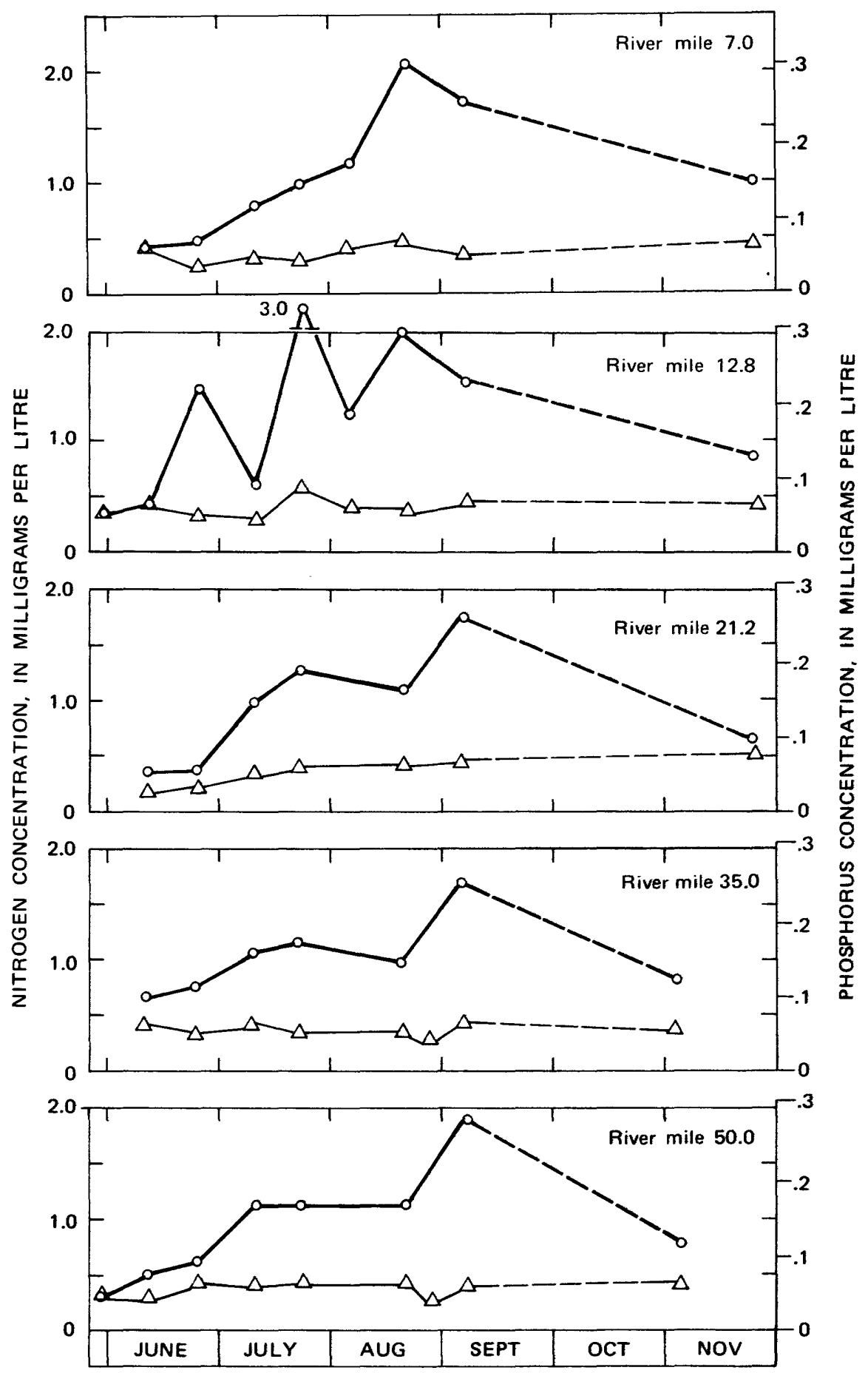

FIgure 4.-Time and spatial variations of dissolved major nutrient concentrations in the Willamette River, June-November 1974: O, ammonia, nitrite, and nitrate as nitrogen; $\Delta$, orthophosphate as phosphorus.

Plots for total-dissolved nitrogen and phosphorus that were prepared in the same molar ratio showed relationships similar to that observed in figure 4 .
The concentrations of dissolved reantive silica (fig. 5) ranged from about 4 to $10 \mathrm{mg} / \mathrm{l}$ and thus were at all times above those required for diatom 

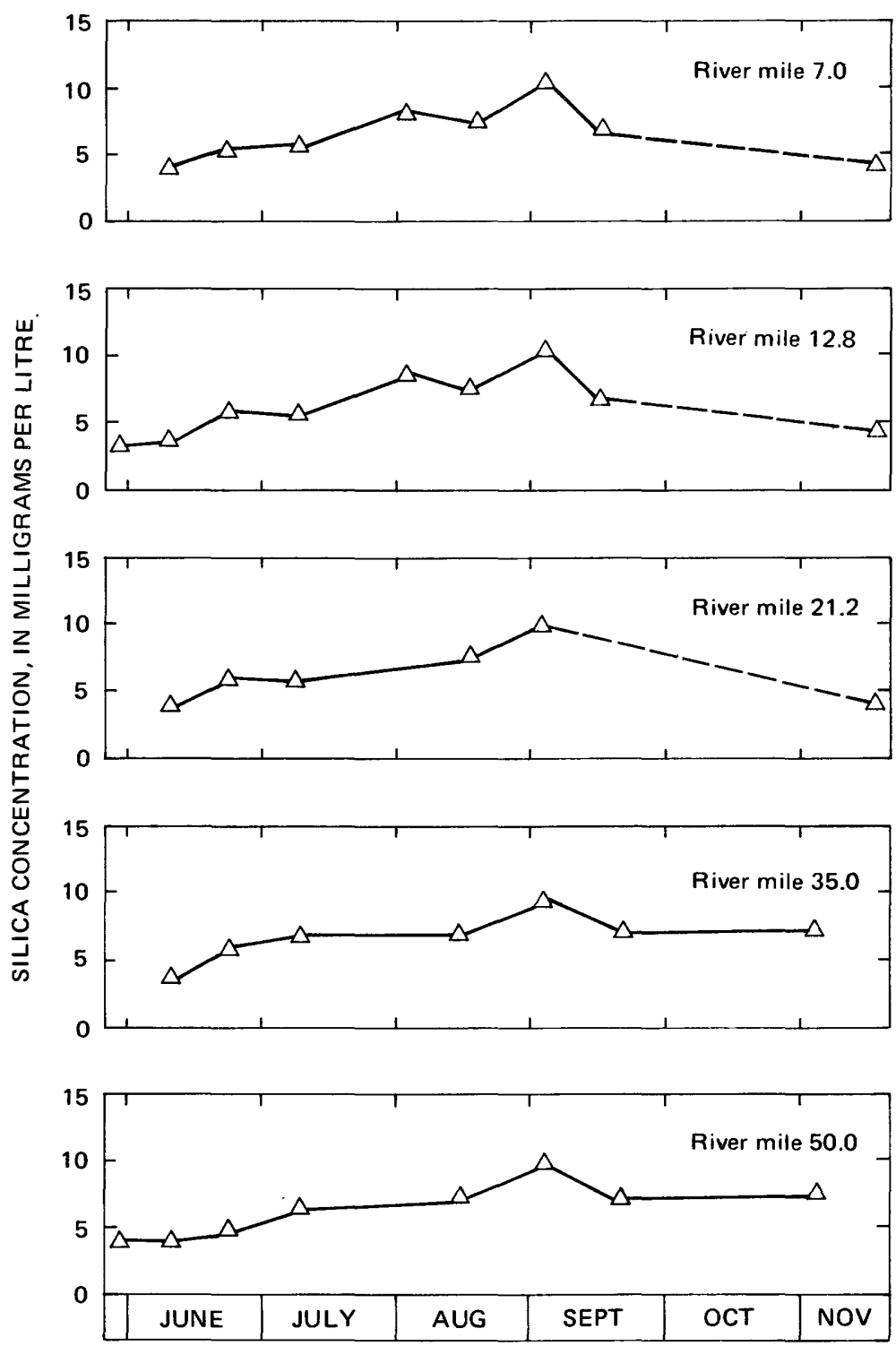

FIGURE 5.-Time and spatial variations of dissolved silica concentrations in the Willamette River, June-November 1974.

growth (Kilham, 1971). The data show no evidence of a decrease in silica concentration from upstream to downstream locations. Additional samples collected between RM's 183 and 50 showed similar results. Thus, there was no apparent downstream depletion of dissolved silica in spite of the presence of suspended diatoms throughout the river and extensive beds of periphytic diatoms above RM 52.

\section{TEMPERATURE}

Water temperatures in the Willamette River and in all tributaries reach a maximum during the July-August low-flow period. T* water temperatures in the Newberg Pool and the Tidal Reach are controlled primarily by ambient air temperatures. Records compiled by the Willamette Basin Task Force (1969) indicate the average temperature during July ranges from about $20^{\circ} \mathrm{C}$ (Celsius) at RM 50 to about $22^{\circ} \mathrm{C}$ at RM 7 .

Figure 7 shows the minimum and maximum daily temperature for the Willamette at RM 7.0 for the period May-September 1974. Water temperature was about $10^{\circ} \mathrm{C}$ in mid-May and in- 


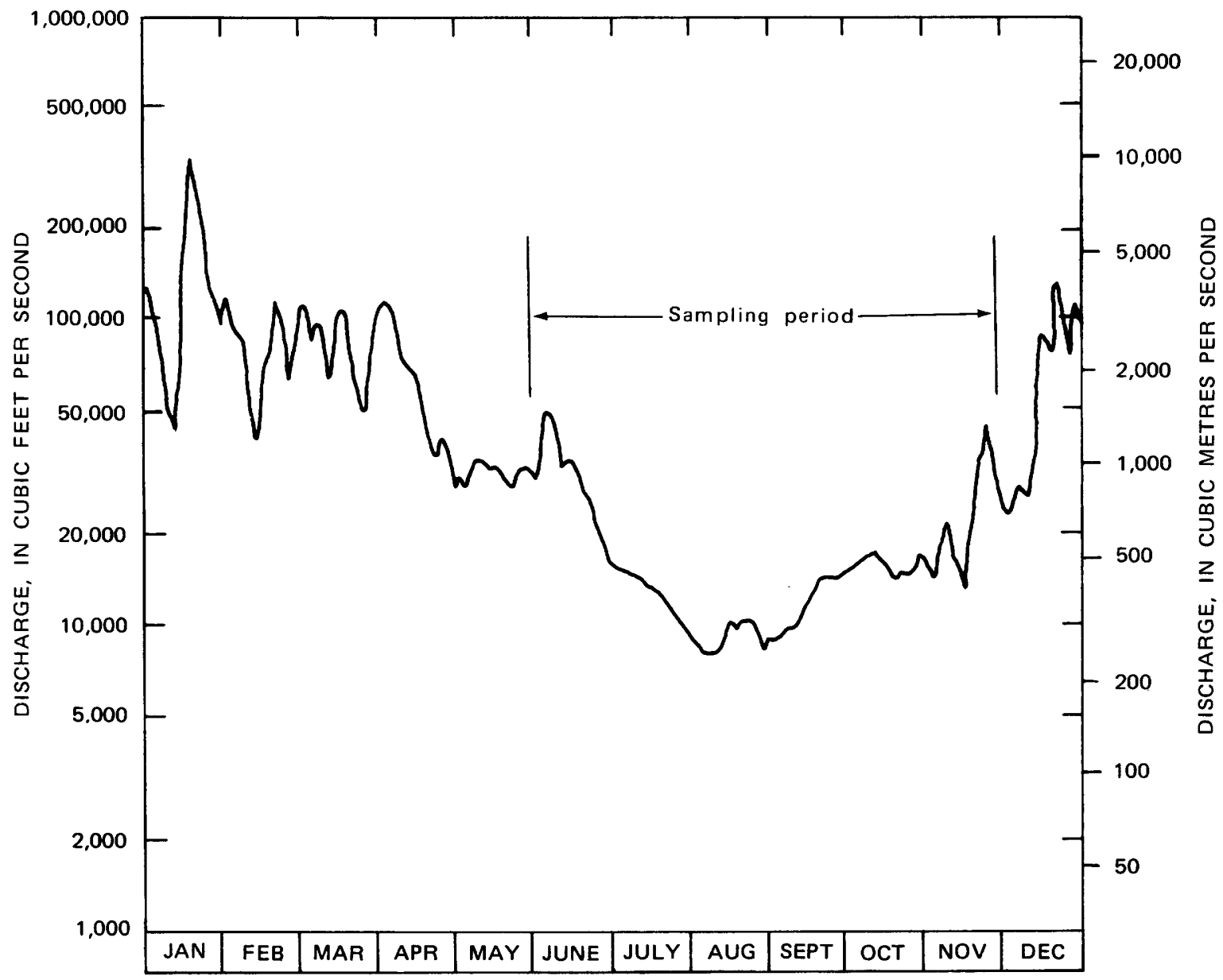

FIgURE 6.-Hydrograph of the Willamette River at Portland, 1974.

creased to only $13^{\circ} \mathrm{C}$ by mid-June. From this date, the temperature increased rather steadily to a maximum of about $24^{\circ} \mathrm{C}$ in early August. The temperature stayed about $20^{\circ} \mathrm{C}$ through the remainder of August and early September and then decreased steadily through the remainder of September.

\section{LIGHT PENETRATION}

The water in the lower Willamette was relatively turbid during the study periods in 1973 and 1974. Extinction coefficients, calculated from the measurement of relative light at the $10-\mathrm{ft}(3-\mathrm{m})$ depth, were between $1.4 \mathrm{~m}^{-1}$ and $2.0 \mathrm{~m}^{-1}$. Coefficients calculated for the $3-\mathrm{ft}(1-\mathrm{m})$ depth were somewhat higher owing to selective wavelength absorption.

The euphotic zone of a water body is the thickness of the surface layer that receives sufficient light to permit algal photosynthesis to equal or exceed algal respiration. This thickness is approximately equal to the depth to which 1 percent of the surface light penetrates. The determined range of extinction coefficients implies a euphotic-zone thickness between 7.5 to $11.5 \mathrm{ft}$ ( 2.3 to $3.5 \mathrm{~m}$ ) along the course of the Willamette River (fig. 8).

Only a small part of the high light extinction results from the presence of suspended algal cells. Talling (1960) reported that a growth of $A s$ terionella in Lake Windermere produced an increase in the extinction coefficient of 0.02 to $0.05 \mathrm{~m}^{-1} / 10^{9}$ cell $\mathrm{s} / \mathrm{m}^{3}$. Diatoms dominated the algal populations in the Willamette (see "Algal Populations"), and observed counts were on the order of 3 to $4 \times 10^{9}$ cells $/ \mathrm{m}^{3}$. Thus, at most, about 10 percent of the observed extinction coefficient of 1.5 to $2.0 \mathrm{~m}^{-1}$ in the Willamette can be ascribed to self-shading. 


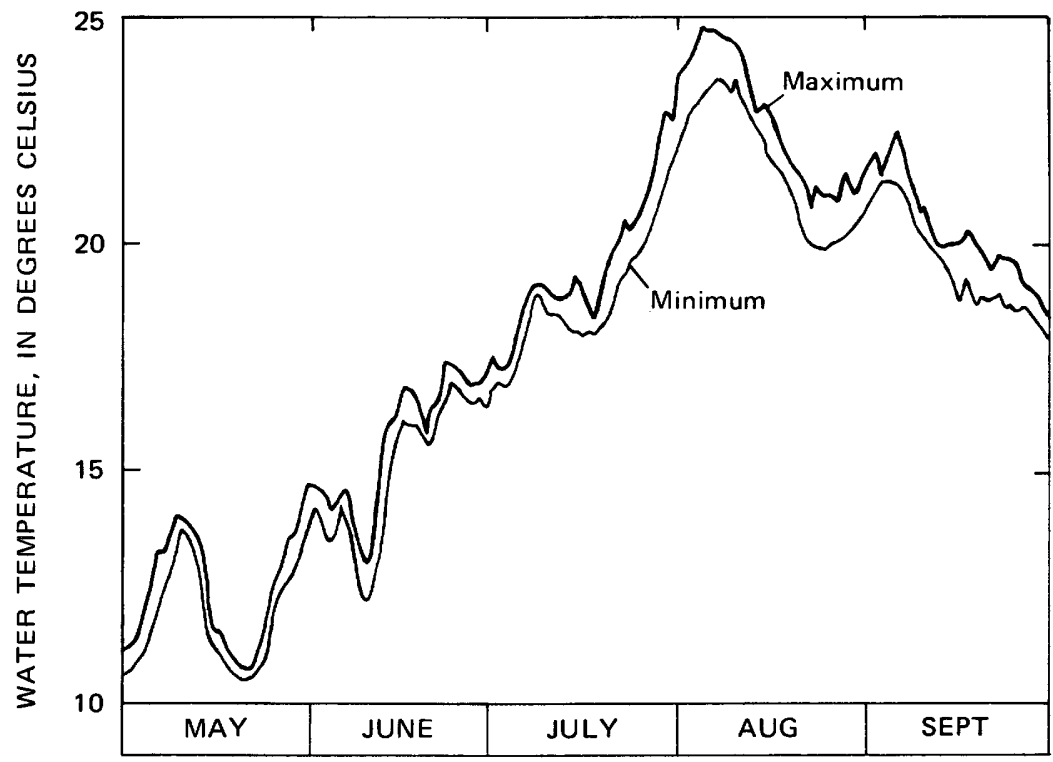

Figure 7.-Daily water temperatures at mile 7.0, Willamette River, MaySeptember 1974.

Light-microscope examination of the nonalgal suspended matter showed it was composed of both organic and inorganic particles. However, the exact natures and sources of these particles have not been determined.

\section{ALGAL POPULATIONS}

\section{GENERAL CHARACTERISTICS}

Diatoms dominated the suspended-algae populations at all sites during both 1973 and 1974 . (Examples of results are presented in tables 4 and 5, at the end of the report.) The most common diatom genera were Melosira, Stephanodiscus, Cymbella, Achnanthes, Nitzschia, and Fragilaria. Some blue-green algae and a variety of colonial green algae also appeared but were less abundant than the diatoms.

Densities of diatoms were rather high, with individual species present in abundances of $10^{2}$ to $10^{3}$ cells $/ \mathrm{ml}$. During both years, the diatom populations were remarkably stable. The same species persisted, and there were no major changes in the total abundance of cells with location (sampling station). However, minor changes in algal populations did occur, as can be seen in figures $9-15$ and in the ensuing discussion of assemblages.

Of the 40 some genera, species, and groups of identified algae (see tables 4 and 5), the seven presented in figures 9-15 provide a summary picture of phytoplankton populations in the deep, slow-velocity reaches (table 1) of the Willamette River. Stephanodiscus hantzschii (fig. 9) and Achnanthes minutissima (fig. 10) were the most abundant organisms at all five statiors during the 1974 sampling period. Both species are widely distributed in rivers throughout the United States, with Stephanodiscus hantzschii found primarily in eutrophic waters (Hustert, 1930; Huber-Pestalozzi, 1942) and Achnanthes minutissima occurring under a wide range of conditions (Patrick and Reimer, 1966).

Melosira distans (fig. 11) was prominent at RM's 7.0 and 12.8 in late summer but was less abundant at these stations in June and July and throughout the sampling period at R.M's 21.2, 35.0 , and 50.0. This species is especially abundant in Southeastern rivers (Weber, 1971), so the increasing counts in the lower Willamette during June through mid-August may be related to increasing water temperatures.

Throughout the 1974 sampling perind Cymbella ventricosa (fig. 12) was present in counts ranging from 10 to $10^{2}$ cells $/ \mathrm{ml}$ at RM's 7.0 and 12.8 and in counts exceeding $10^{2}$ cells $/ \mathrm{ml}$ at the three upstream stations. This species grows attached to surfaces such as river bottom rocks (periphytic or benthic) rather than suspended 


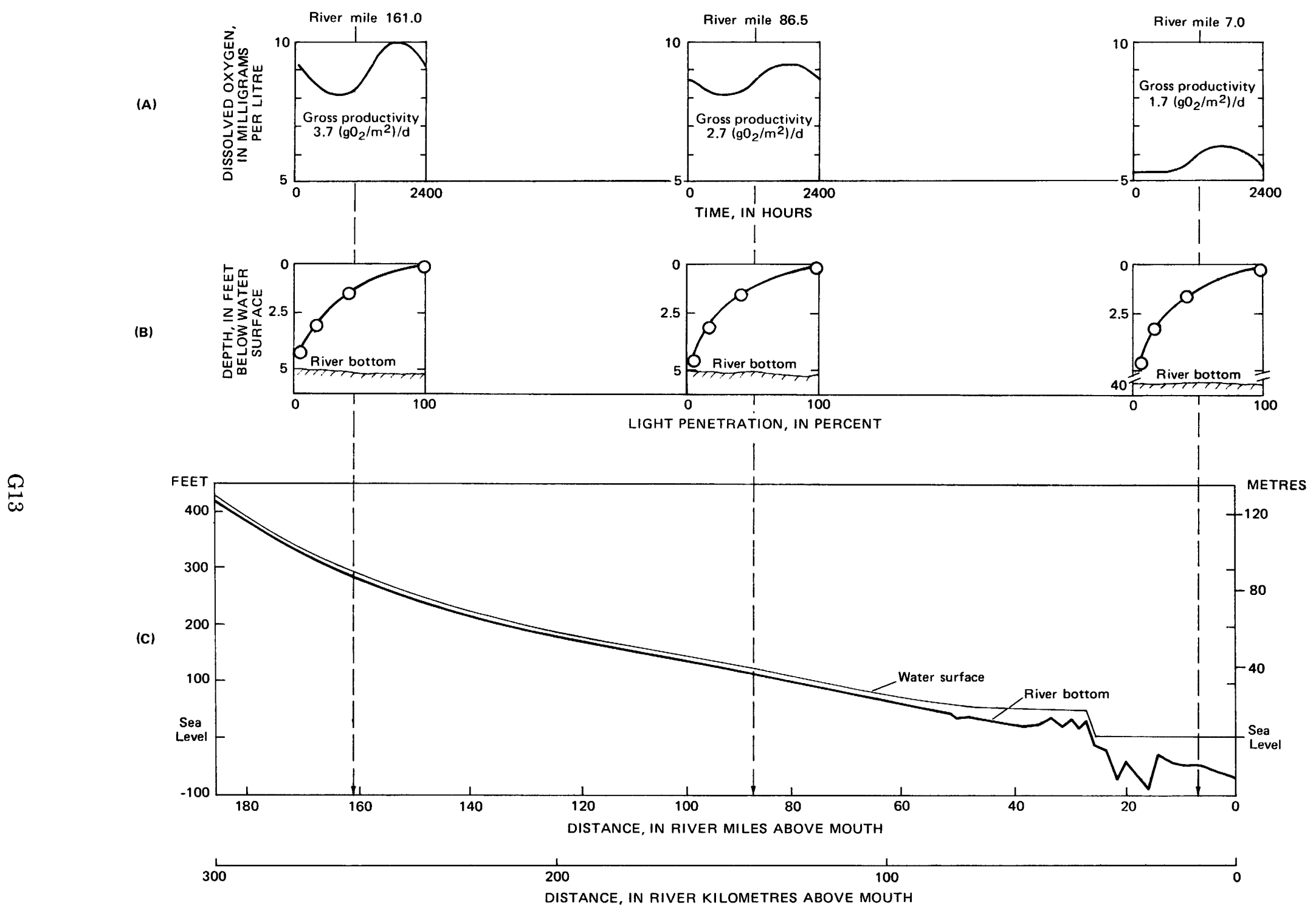

Figure 8.-(A) Diel dissolved-oxygen curves and calculated gross productivities, (B) light penetration as a function of water depth, and (C) elevation profiles for summer low-flow conditions of the Willamette River, mid-July 1973. 

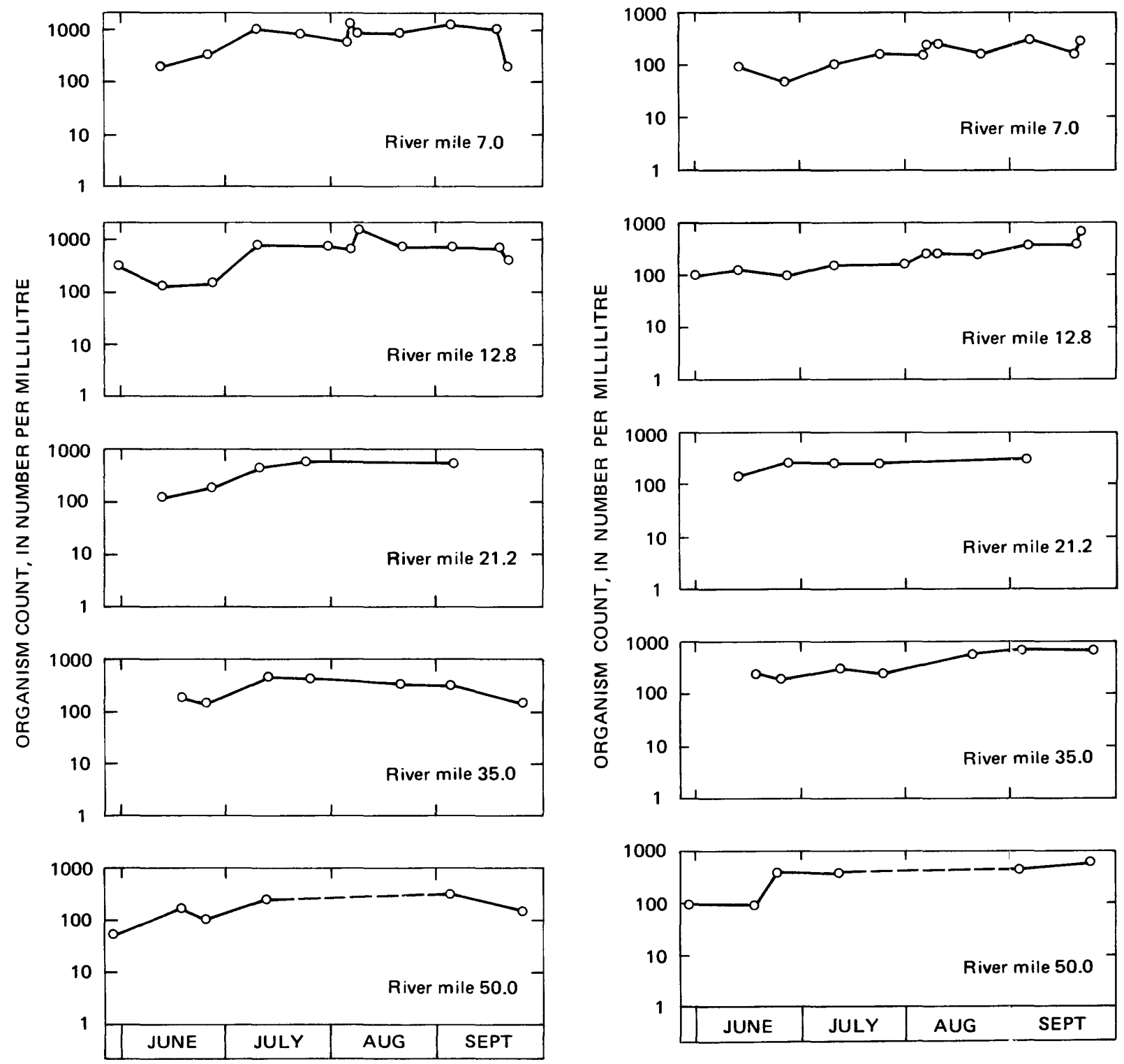

Figure 9.-Abundance of Stephanodiscus hantzschii, by station and time, in the Willamette River, JuneSeptember 1974.

(planktonic) in water (Huber-Pestalozzi, 1942). The greater abundance at upstream sites is consistent with the presence of extensive beds of periphyton in the Willamette above RM 52 (in the Upstream Reach).

In contrast, Asterionella formosa (fig. 13), a classic planktonic diatom (Huber-Pestalozzi, 1942; Patrick and Reimer, 1966), was more persistent and abundant at RM's 7.0 and 12.8 than farther upstream. This species is described as a widely distributed diatom (Weber, 1971), espe-

cially common in eutrophic waters (Hustedt, 1930; Huber-Pestalozzi, 1942).

The green-algae group (fig. 14) was dominated by a colonial form but also included unidentified single-cell and filamentous forms and occasional observations of Scenedesmus and Pediastrum. The group was most persistent and abundant at RM 7.0. At each successive upstream station, its occurrence became increasingly sporadic.

Anabaena (fig. 15) was the only blue-green genus identified in the study. Like the green al- 

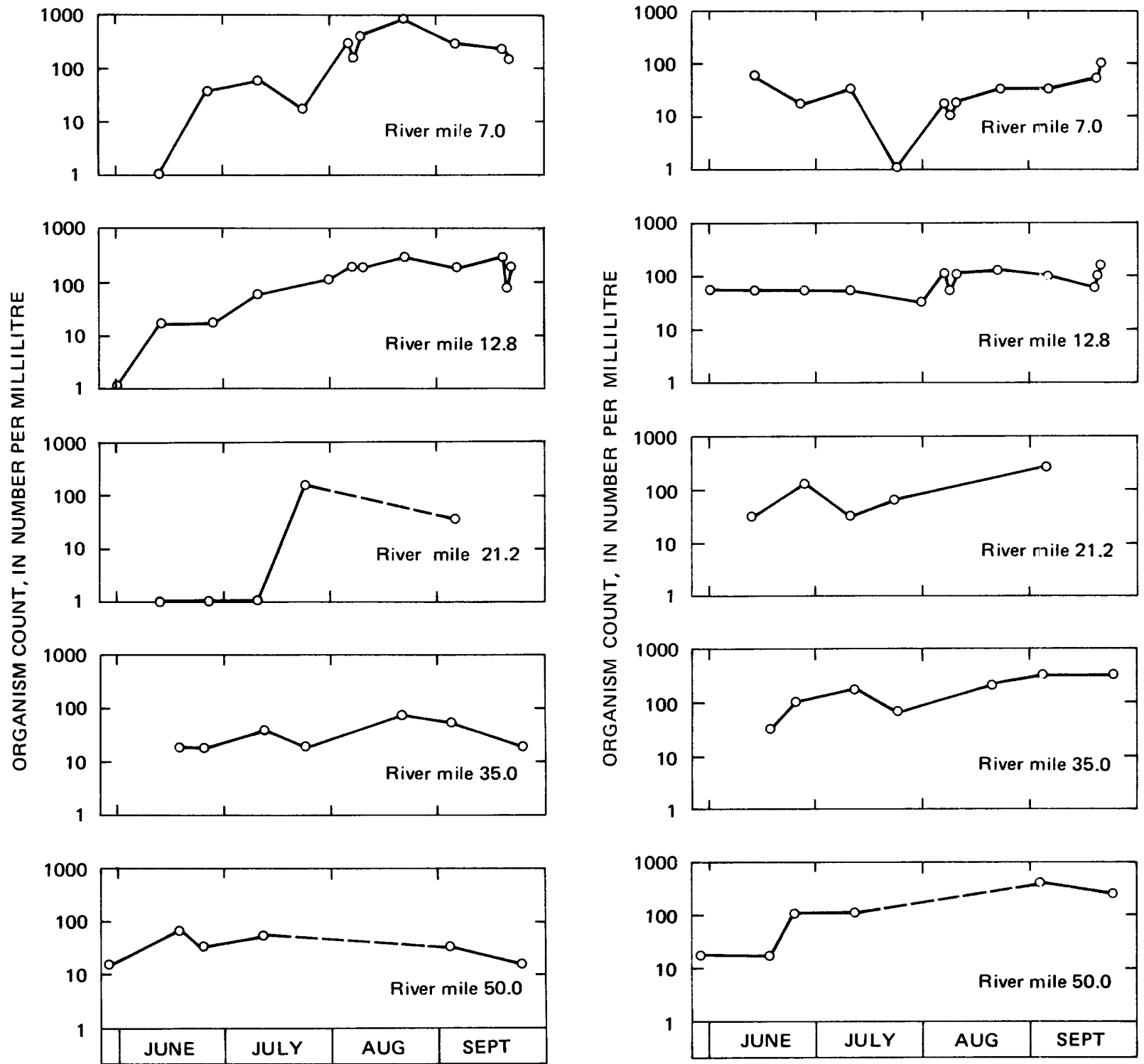

Figure 11.-Abundance of Melosira distans, by station and time, in the Willamette River, June-September 1974.

gae, Anabaena was most persistent and abundant at RM 7.0.

Figure 16 shows the abundance of selected algae during early August 1973. With the exception of Anabaena, the counts and relative location shifts are similar to those noted for the same time period during 1974 (figs. 9-15).

The common species of diatoms observed in the Willamette can be characterized as cosmopolitan and eutrophic. No species appeared that would indicate highly polluted conditions, although

some of the common diatoms are moderately tolerant of organic enrichment (Palmer, 1969). Although short filaments of Anabaena were observed in some samples, no "blooms" occurred during the course of study. Collectively, the composition of all suspended algae suggests that the lower two reaches of the Willamette were nutrient enriched but not grossly polluted.

Only a few of the diatom species observed in the lower river can be regarded as unexuivocally planktonic. Melosira granulata and Melosira 

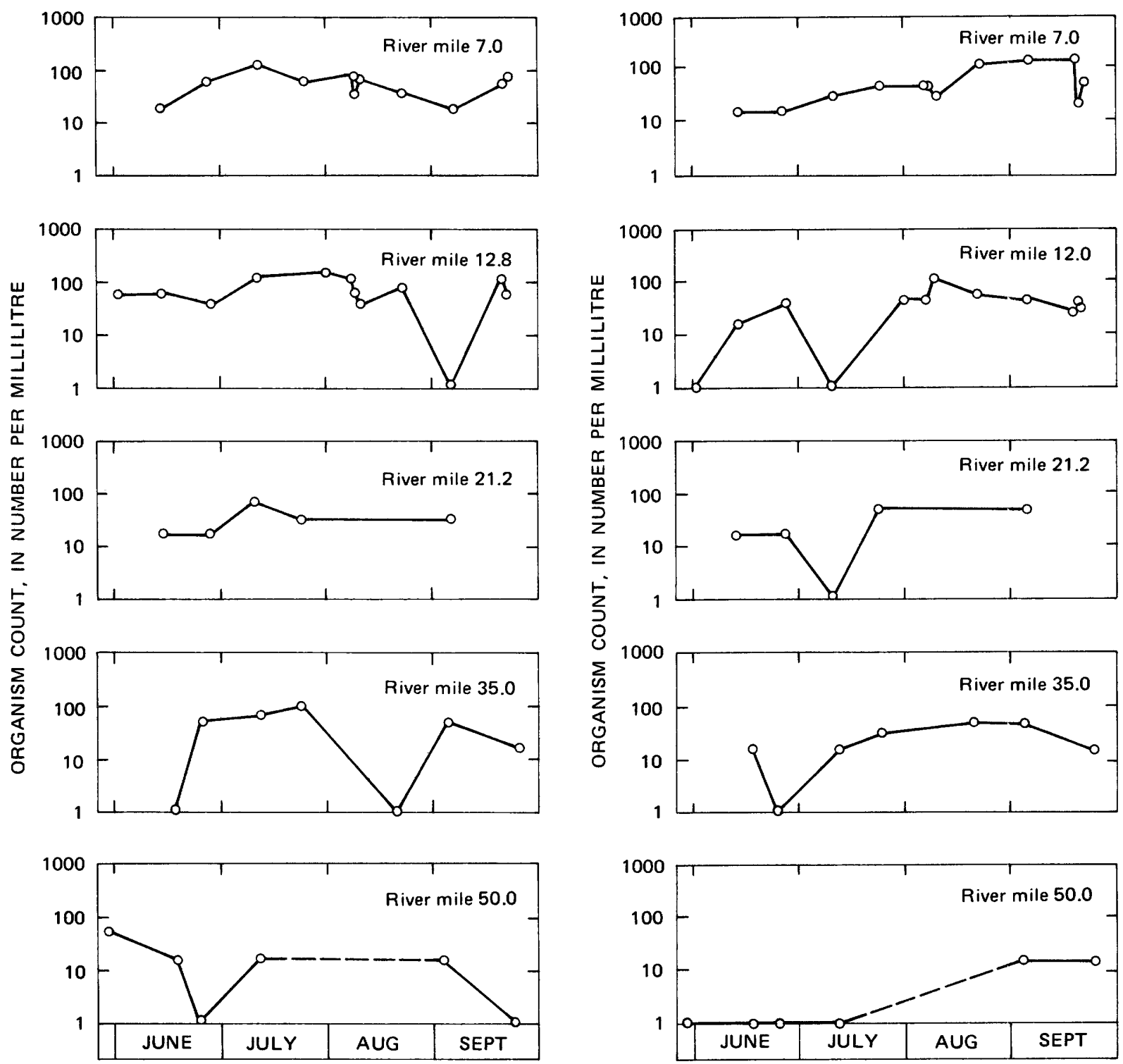

Frgure 13.-Abundance of A sterionella formosa, by station and time, in the Willamette River, June-September 1974.

italica were present at all sampling stations in moderate abundance and can be regarded as truly planktonic types. Asterionella formosa and Fragilaria crotonensis also appeared, but generally in low abundance. In contrast, a number of commonly observed diatoms were probably derived chiefly from upstream periphyton; these included Rhiocosphenia curvata, Cymbella ventricosa (as previously noted), other species of Cymbella, and several species of Nitzschia. In addi-

tion, a third category of diatoms included species that possibly were derived from upstream periphyton but that are frequently observed in the suspended plankton of rivers (Williams, 1964, 1972). These facultative planktonic types included Achnanthes minutissima, Melosira distans, and Synedra ulna.

The aggregate nature of diatoms in the lower Willamette indicates that the population resulted from both in-river growth of planktonic forms 

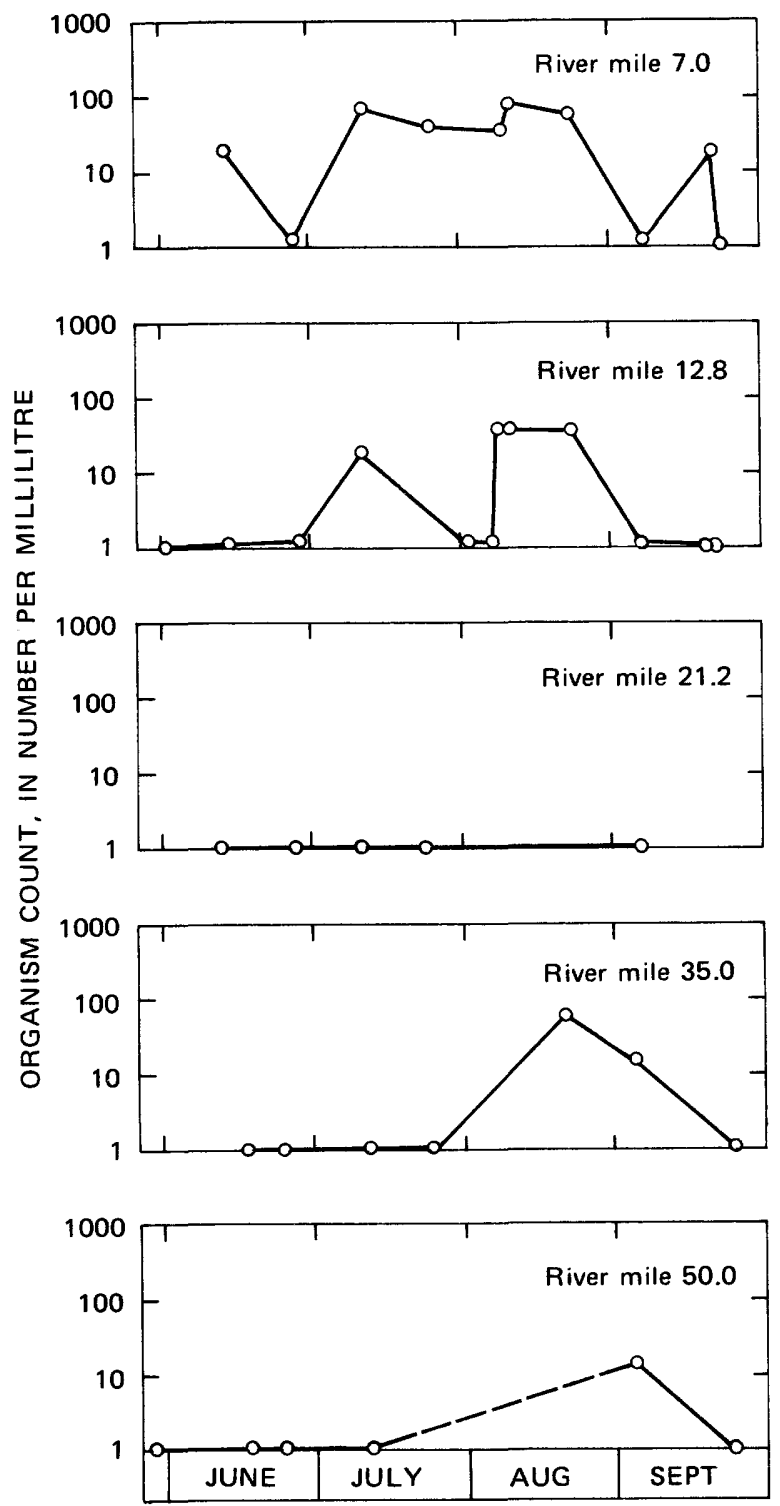

Figure 15.-Abundance of Anabaena spp., by station and time, in the Willamette River, June-September 1974.

(see "A Downstream Traverse") and the exportation of cells from upstream (above RM 52) benthic communities.

\section{ASSEMBLAGES}

The algal-count data were analyzed according to a cluster analysis procedure (Hartigan, 1975) to determine if there was any evidence of identifiable subgroups or population assemblages. By using a K-means algorithm, the counts were first assigned to the two groups that gave the mini- mum variance. By the same technique, the counts were assigned to the best three, four, and five groups in succession. The clusterirg based on three groups produced three compact assemblages related to both sampling time and location (fig. 17). Clusters of four and five were also readily identified but added relatively little information.

The three clusters shown in figure 17 represent (1) all the early samples, from May through June, (2) most of the lower three stations from July through mid-September, and (3) upstream stations from July through mid-September and some of the samples at RM's 12.8 and 21.2 in September.

The clustering of the three groups resulted from the abundance of the commoner species together with the relative abundance of some of the less common species. The samples from early in the year (Group 1) consisted of moderate abundances of Achnanthes minutissims:, Nitzschia spp., and Stephanodiscus hantzschii, with occasional moderate counts of other species. The second cluster, from the three downstream stations and from July-September, consisted of relatively high abundances of Stephanodiscus hantzschii, Achnanthes minutissima, Nitzschia spp., and some Cymbella ventricosa. The third cluster, representing the more upstream samples from July-September (fig. 17), was disting xished from the other two primarily by the presence of additional species (Cymbella spp., Stephanodiscus astrae, and others) which occurred in moderate abundance. Thus, this third cluster represented a somewhat more diverse assemblage than the other two.

Overall, the cluster analysis shows that from mid-July through mid-September, there was some evidence for a downstream progression in species composition. The changes were not pronounced, however, and consisted principally of some of the moderately abundant species becoming less significant.

\section{A DOWNSTREAM TRAVERSE}

During the period August 5-7, 1974, water samples were collected for suspended-plankton analysis during a raft traverse of the entire Willamette main stem. Figure 18 presents selected results for 17 sites on the Willamette, with additional data on the McKenzie, Santiam, and Yamhill Rivers. Data shown for RM 35.0 are in- 


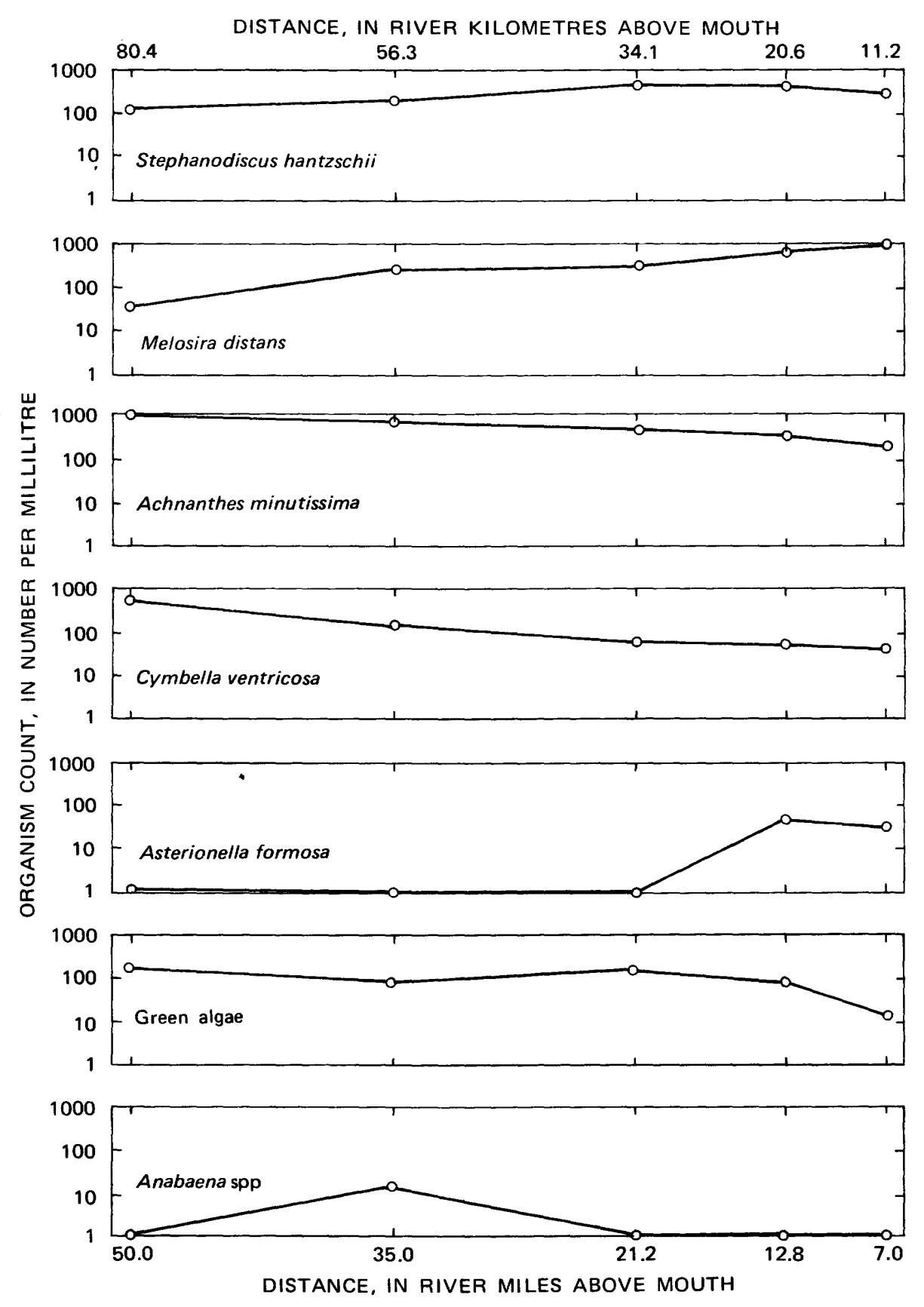

FIGURE 16.-Abundance of selected algae in the Willamette River, August 7, 1973.

cluded from July 23 , when flow and water temperatures were nearly identical to those of August 5-7.

The plots show that Achnanthes minutissima is the only diatom species that occurs in high abundance over the entire main stem. Stephanodiscus hantzschii was not observed at RM 169 downstream from the McKenzie River but increased gradually thereafter to reach maximum counts in the Tidal Reach. Melosira distans was not observed above RM 60, but below this location it increased gradually to maximum abundance at RM 7.0. The periphytic Cymbella ventricosa occurred sporadically above RM 131 and then in- 


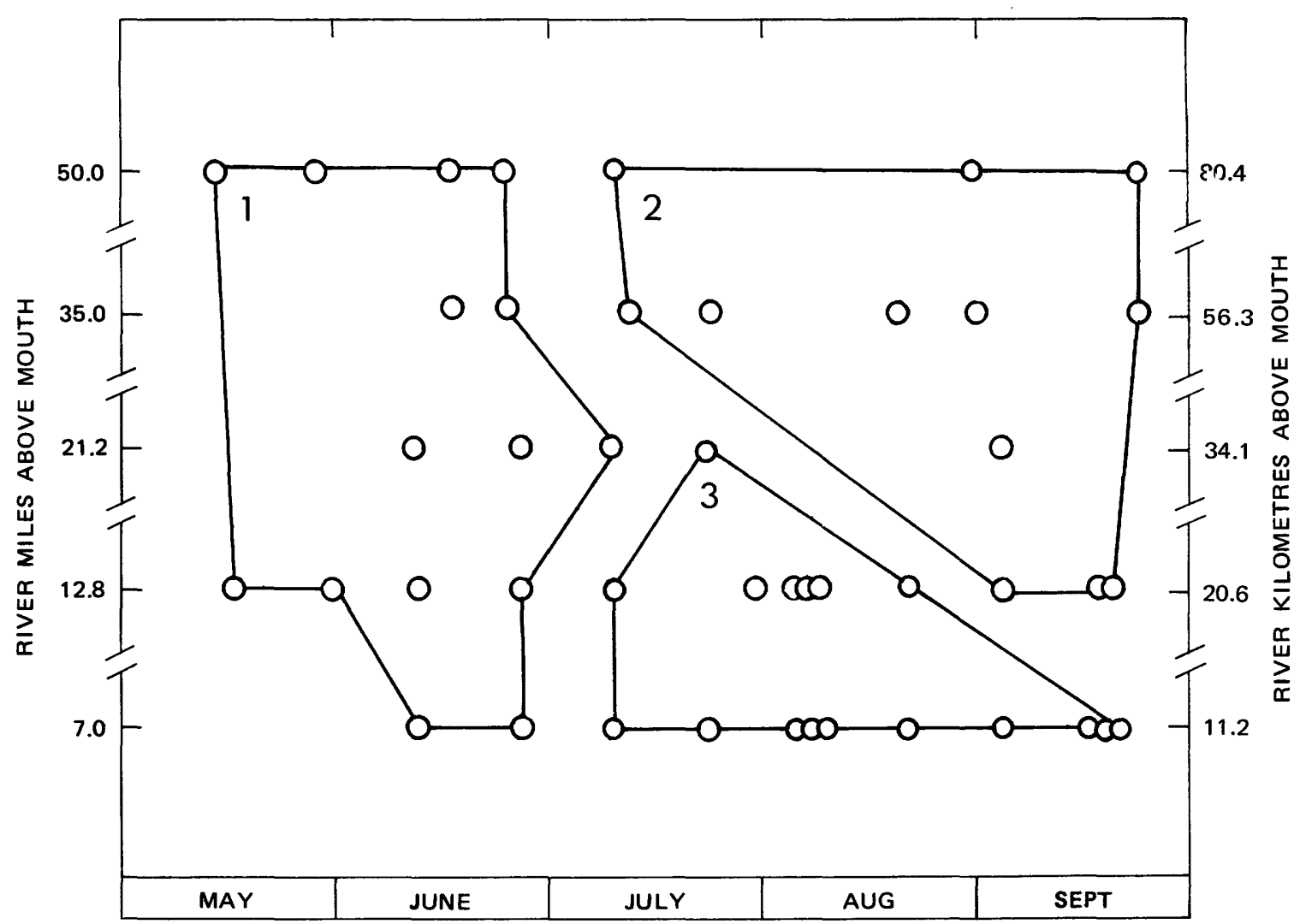

FIgURE 17.-Summary of the time and spatial distribution of algal populations in the Willamette River, MaySeptember 1974. (Numbered groups are explained in text.)

creased to levels on the order of $10^{2}$ cells $/ \mathrm{ml}$ throughout the remainder of the Upstream Reach. This general abundance was fairly well maintained throughout the Newberg Pool down to RM 12.8. The planktonic Asterionella formosa occurred sporadically over the entire river but was most abundant at the lower four stations, beginning at RM 35.0. The spatial distribution of both Asterionella formosa and Melosira distans (and perhaps even Stephanodiscus hantzschii) suggests that these algae were actively growing below RM 35.0 rather than merely derived from growth in upstream reaches or reservoirs.

Green algae were not observed above RM 78, and the highest counts were from the Tidal Reach. In contrast, Anabaena was observed in low abundance in three distinct pockets located at the beginning of the main stem to RM 169, at RM's 90 and 78, and in the Tidal Reach. The patchy occurrence of Anabaena spp. is suggestive of derivation from outside the river rather than growth within the river. The Anabaena spp. at the upper end of the Willamette may have originated in upstream reservoirs, whereas the filaments observed at $\mathrm{RM}$ 21.2 possibly entered from the Tualatin River.

Total algal counts from the traverse (fig. 18) increased from the uppermost sampling points to the four lowermost stations, with a peak abundance at RM 50.0. Specifically, the counts were between about 1,000 and 1,200 at RM's 183 to 169 , between 1,600 and 2,100 at RM's 152 to 131 , between 2,300 and 2,900 at RM's 120 to 60 , more than 3,200 at RM 50.0, and then back down to the 2,300-2,900 level below RM 35 .

Figure 18 shows interesting contrasts of algal populations in the McKenzie, Santiam, and Yamhill Rivers to those in the Willamette. Of the seven groups presented in the plots, only Achnanthes minutissima and Asterionella formosa were observed in the McKenzie, and the total count was 500 cells $/ \mathrm{ml}$. At the time of sarnpling, the McKenzie was adding about $3,400 \mathrm{ft}^{3} / \mathrm{s}\left(96 \mathrm{~m}^{3} / \mathrm{s}\right)$ to a mainstem flow of $2,100 \mathrm{ft}^{3} / \mathrm{s}\left(59 \mathrm{~m}^{3} / \mathrm{s}\right)$. The dilution effects of the McKenzie are notable in the downstream counts. Of the seven groups noted in figure 18, only Achnanthes minutissima and 

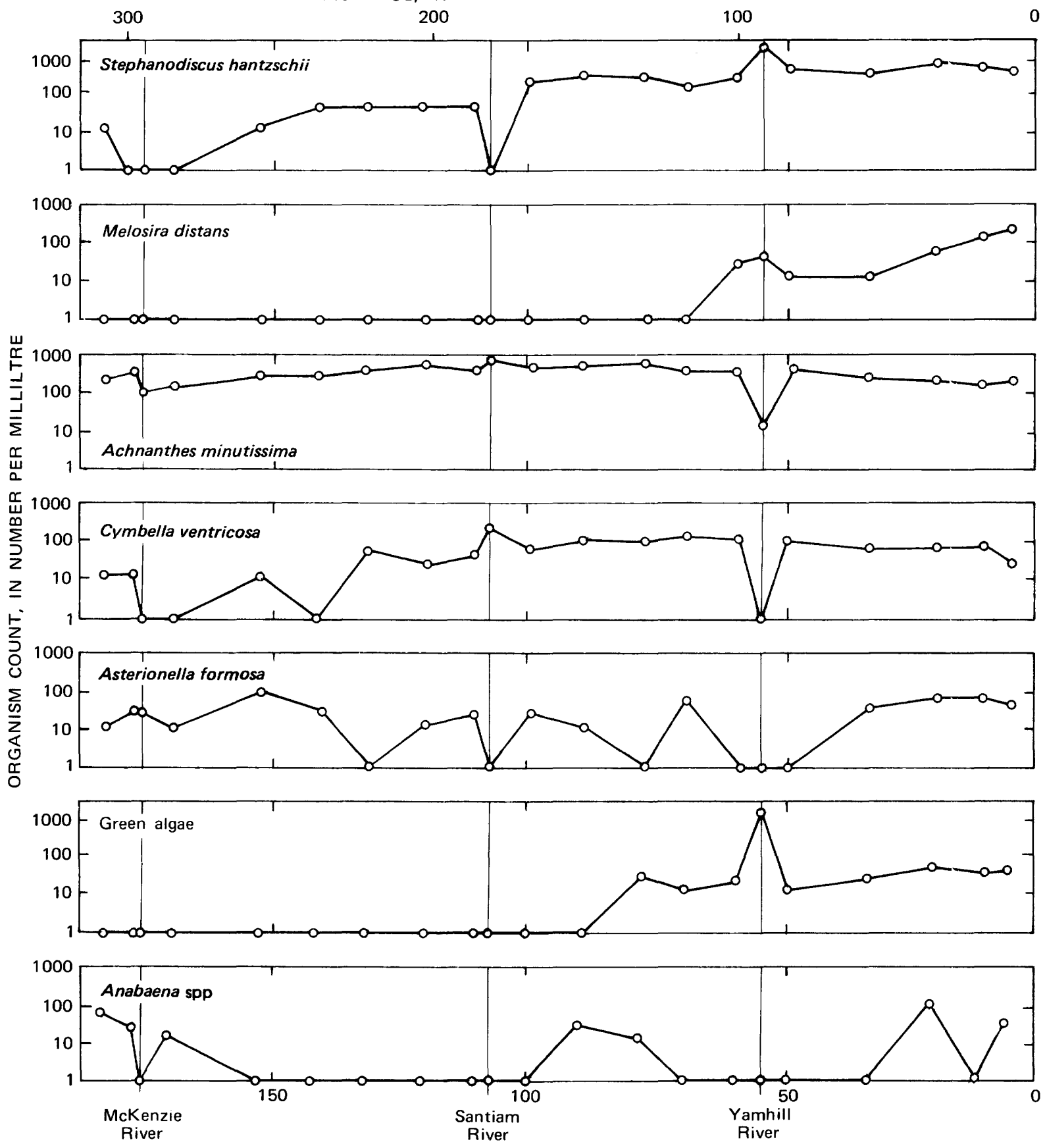

DISTANCE, IN RIVER MILES ABOVE MOUTH

TABLE 18.-Abundance of selected algae in the Willamette River and certain tributaries, August 5-7, 1974. (Values at river mile 35.0 are from July 23 .)

Cymbella venticosa were observed in the Santiam River, and the total count was about 2,000 cells/ $\mathrm{ml}$. The flow in the Santiam was about $1,500 \mathrm{ft}^{3} / \mathrm{s}$ $\left(42 \mathrm{~m}^{3} / \mathrm{s}\right)$.

During summer, the McKenzie and Santiam are swift-flowing, large-volume, low-temperature rivers that originate in the Cascade Fange and are augmented by reservoir releases. Ir contrast, the Yamhill River during summer has low flows, long detention times, and high temperatures 


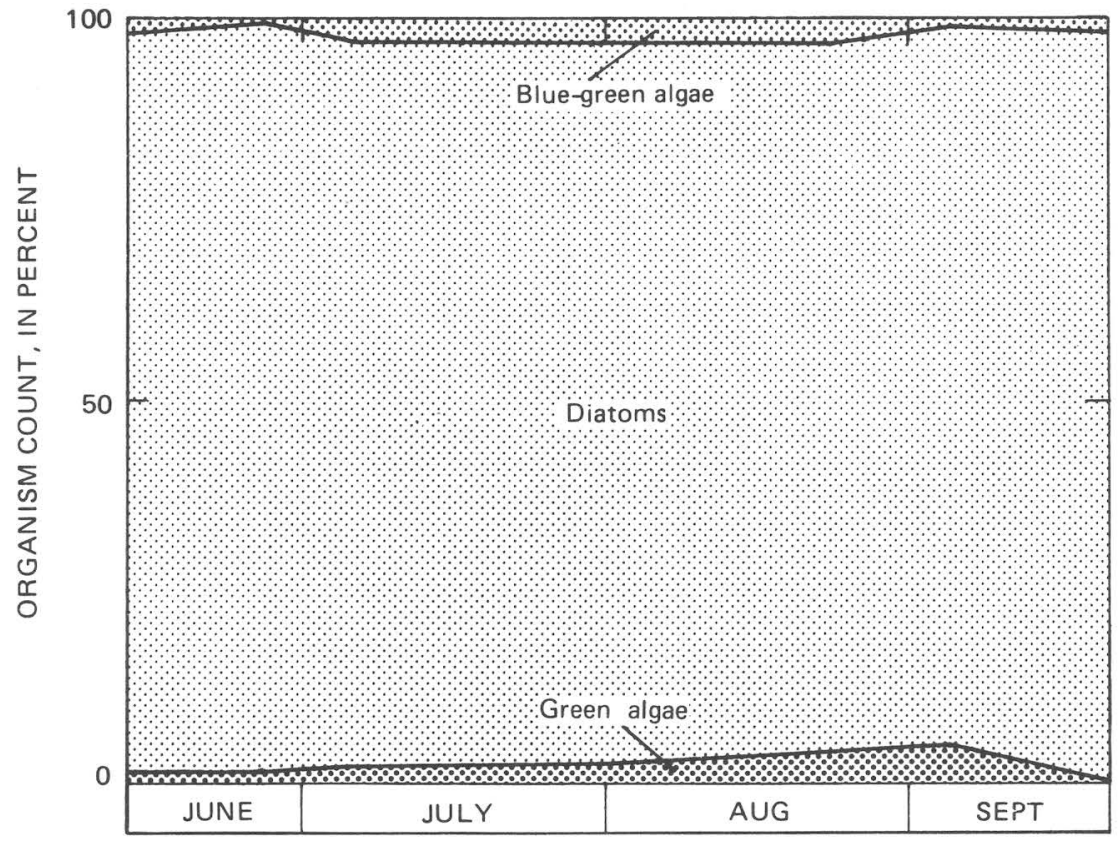

Figure 20.-Time variation of algal types in the Willamette River, at mile 7.0, June-September 1974.

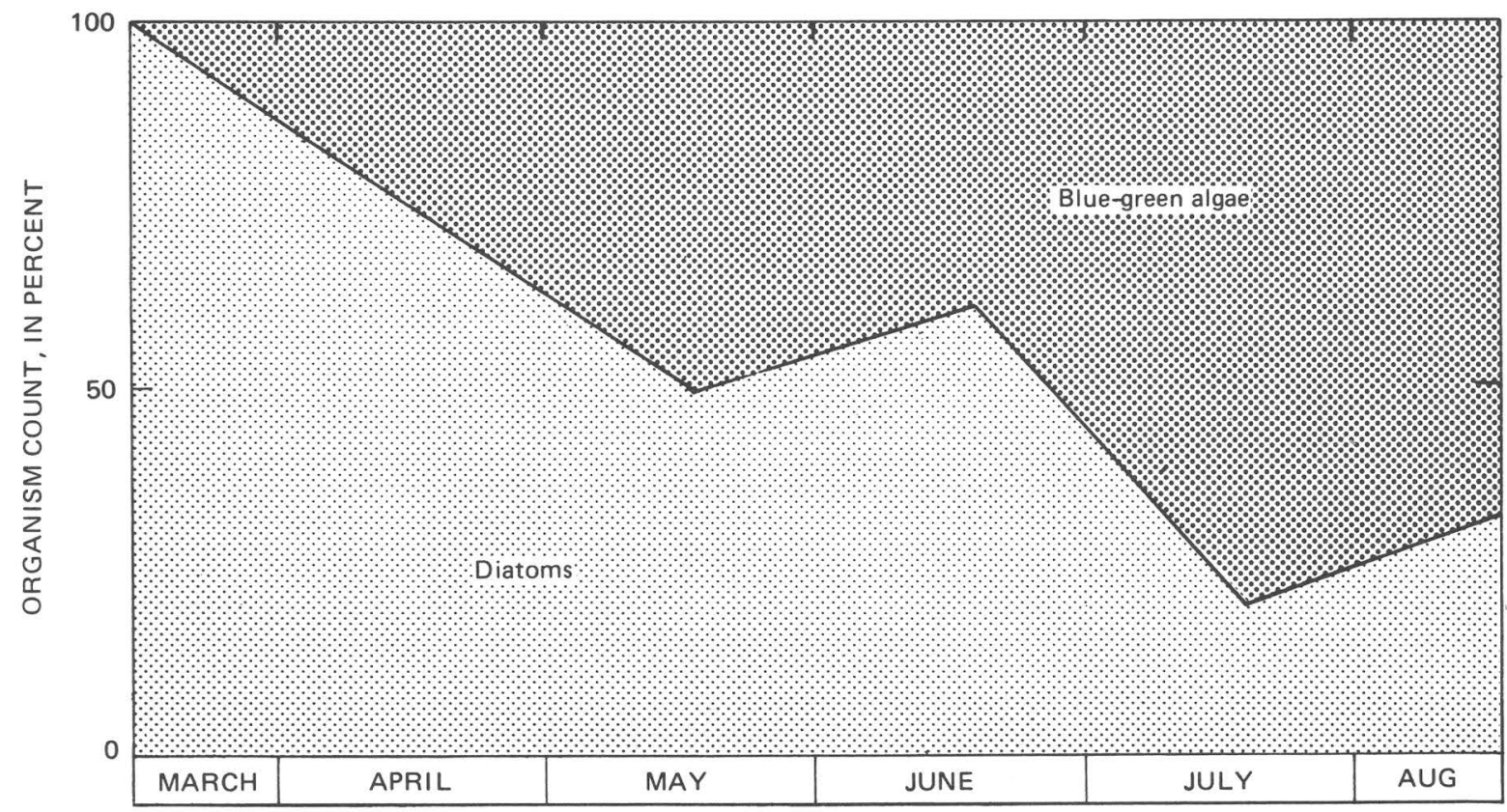

FIGURE 21.-Relative abundance of diatoms and blue-green algae in net plankton of the Tualatin River at Farmington, Oreg., March-August 1973 (Carter, 1975).

light- and dark-bottle method (Slack and others, | measuring the uptake of carbon-14 and convert1973). Vertical distributions of the gross productivities are presented in figure 22 . The values plotted for September 19 were determined by ing the data to equivalent units of oxygen. Values plotted for the other dates were determined by direct measurement of oxygen production. For 


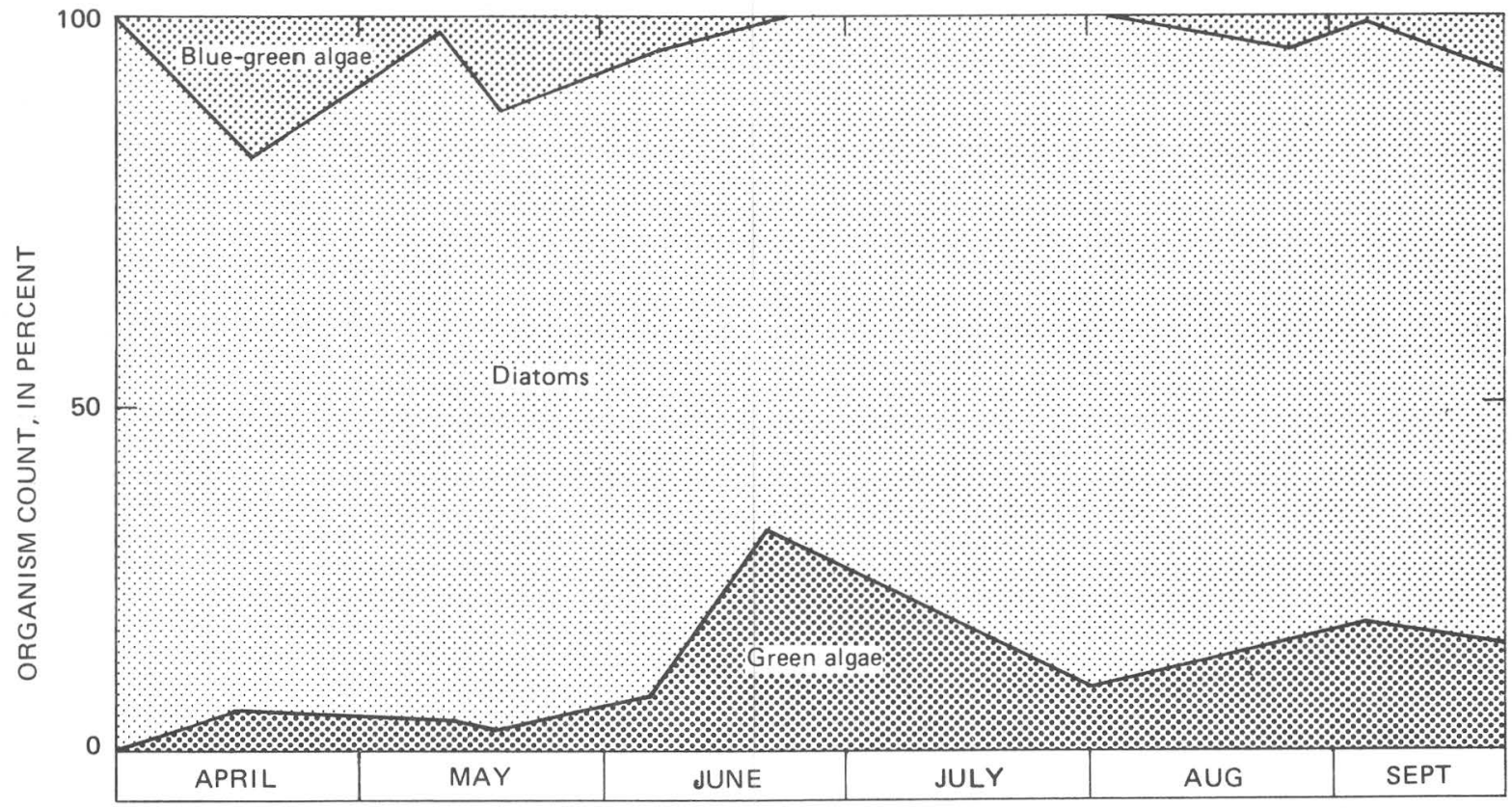

Figure 19.-Time variation of algal types in the Willamette River and certain tributaries, at mile 8.1, April-September 1963 (U.S. Public Health Service, 1964).

(Willamette Basin Task Force, 1969). The Yamhill algal assemblage reflected the river's character. The total algal count exceeded 6,000 cells $/ \mathrm{ml}$, and the dominant forms were a variety of colonial green algae and Stephanodiscus hantzschii. The discharge of the Yamhill on the date of sampling was about $100 \mathrm{ft}^{3} / \mathrm{s}\left(3 \mathrm{~m}^{3} / \mathrm{s}\right)$.

\section{COMPARISON WITH HISTORICAL DATA}

Figures 19 and 20 compare the relative abundances during 1963 (U.S. Public Health Service, 1964) and 1974 of diatoms, green algae, and blue-green algae in the lower Willamette River. Differences in methodology between the two studies could well account for the observed higher abundance of green algae during 1963 (Williams, $1964,1972)$. However, the point of major importance is that the suspended algal population in the lower river was dominated by diatoms in 1963, just as it was during 1973 and 1974. This observation is significant, because the lower Willamette was polluted with sewage and pulp-mill wastes in 1963 (Velz, 1961; Gleeson, 1972) but now is relatively free of such organic pollution (Rickert and others, 1975b). Unfortunately, no 1963 data are available on nitrogen and phosphorus concentrations to provide a comparison of nutrient availability.
The Public Health Service report (U.S. Public Health Service, 1964) also noted that the dominant spring and autumn diatoms were Stephanodiscus hantzchii and Synedra ulna. The 1973 and 1974 data show that Stephanodiscus hantzschii was the dominant late spring and summer species in the lower Willamette; however, Synedra ulna counts were very low or nil during the summer and early fall.

Figure 21 shows the relative abundance of diatoms and blue-green algae in net plankton from the Tualatin River. The illustrated data (Carter, 1975) indicate that the eutrophic but not heavily polluted reach at Farmington was dominated by blue-green algae during July-August 1973. During this period, streamflow in the Tualatin was low, at about $10 \mathrm{ft}^{3} / \mathrm{s}\left(0.3 \mathrm{~m}^{3} / \mathrm{s}\right)$. The Tualatin enters the Willamette at RM 28.6, and, as previously noted (see "A Downstream Traverse"), this tributary inflow may account for the low counts of Anabaena sometimes observed in the Tidal Reach. (See figs. 15, 18.)

\section{PRIMARY PRODUCTIVITY}

\section{LIGHT- AND DARK-BOTTLE METHOD}

Phytoplankton productivity was measured on several occasions at RM's 7.0 and 12.8 by the 

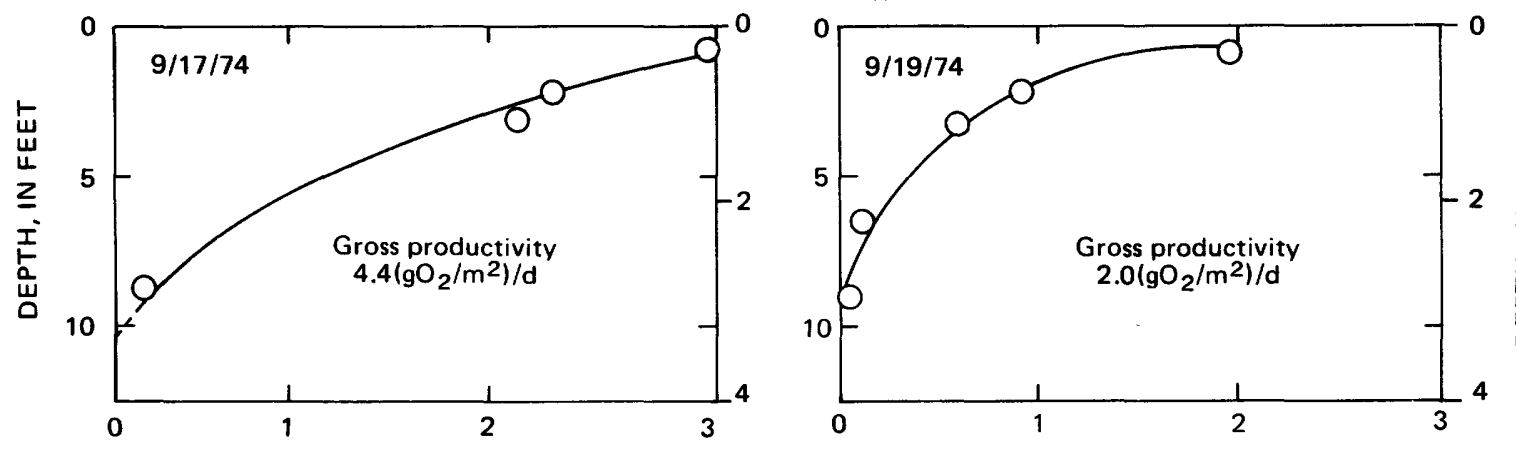

RIVER MILE 12.8
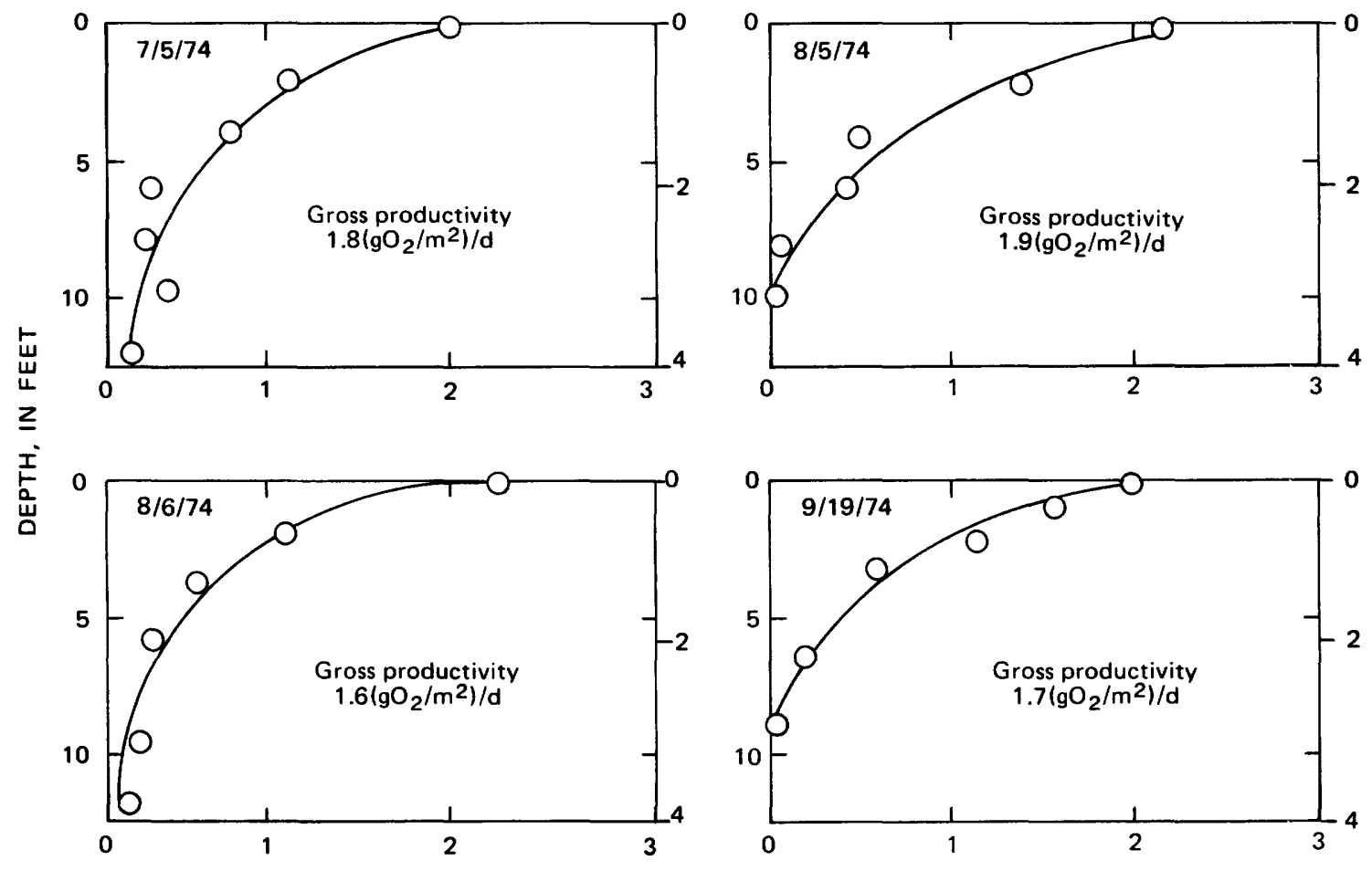

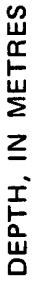

DISSOLVED OXYGEN, PRODUCED IN LIGHT-DARK BOTTLES TESTS, IN MILLIGRAMS PER LITRE PER DAY

FIGURE 22.-Vertical distribution of primary gross productivities in the lower Willamette River, at selected times during summer, 1974. The gross productivity for each euphotic zone, reported as $\left(\mathrm{gO}_{2} / \mathrm{m}^{2}\right) / \mathrm{d}$, was calculated according to Slack, Averett, Greeson, and Lipscomb (1973).

each plot in figure 22 , the area enclosed by the smooth curve has been integrated to obtain a total gross productivity for the euphotic zone. (See "Light Penetration.") These results, which represent the productivity of a vertical column of water $1 \mathrm{~m}^{2}$ in cross section, ranged from 1.6 to 4.4 $\left(\mathrm{gO}_{2} / \mathrm{m}^{2}\right) / \mathrm{d}$ (grams DO per square metre per day).

The measured rates of productivity are low but, nevertheless, indicate that the suspended algae in the lower Willamette were metabolically active rather than dead cells transported from the periphytic beds above RM 52 .

The vertical distributions show that gross productivity decreased rapidly with depth, a result consistent with the low light transmission properties of the water. The clarity of the water varied over the summer, but the depth of the euphotic zone at the two stations was usually 
within the range of 8 to $11.5 \mathrm{ft}(2.4$ to $3.5 \mathrm{~m})$. In contrast, the depth of the total water columns was $42 \mathrm{ft}(12.8 \mathrm{~m})$ at $\mathrm{RM} 7.0$ and $37 \mathrm{ft}(11.2 \mathrm{~m})$ at $\mathrm{RM}$ 12.8 (fig. 8).

Net productivity was determined from gross productivity by subtracting community respiration as calculated from the results of extensive BOD (biochemical oxygen demand) tests (Hines and others, 1977). This approach for calculating respiration was used so that net production could be estimated for the entire water column as well as for the euphotic zone. At RM 7.0, the resultant net productivities were 1.3 and $3.7\left(\mathrm{gO}_{2} / \mathrm{m}^{2}\right) / \mathrm{d}$ for the euphotic zone and -1.7 and $+0.7\left(\mathrm{gO}_{2} / \mathrm{m}^{2}\right) / \mathrm{d}$ for the water column. At RM 12.8, the net productivity values were $1.3,1.4,1.5$, and $1.7\left(\mathrm{gO}_{2} /\right.$ $\left.\mathrm{m}^{2}\right) / \mathrm{d}$ for the euphotic zone and $0.1,0.2,0.3$, and $0.4\left(\mathrm{gO}_{2} / \mathrm{m}^{2}\right) / \mathrm{d}$ for the water column.

The total water-column values indicate that for RM 12.8 oxygen produced by algal photosynthesis approximately balanced the oxygen consumed by community respiration on each of the 4 days. In contrast, at RM 7.0, the oxygen produced exceeded that consumed by a small amount on September 17, but oxygen consumption exceeded production by a considerable margin on the 19th. These reported values for water column net productivity are based on several assumptions and can be considered only as estimates. Nevertheless, the values are in general accord with the DO regimen of the Willamette as described by Hines, McKenzie, Rickert, and Rinella (1977).

\section{OXYGEN-CURVE METHOD}

Primary production has also been estimated by graphical analysis (Slack and others, 1973) of diel oxygen curves obtained by continuous recording monitors. Figure 8 presents the DO curves, lighttransmission plots, and estimated gross productivities at three stations, for virtually cloudless days, during mid-July 1973. The stations at RM's 161 and 86.5 were shallow and dominated by periphyton. The entire water column at these sites was illuminated, a condition characteristic of most of the Upstream Reach. The gross productivities observed under these conditions were 3.7 $\left(\mathrm{gO}_{2} / \mathrm{m}^{2}\right) / \mathrm{d}$ at $\mathrm{RM} 161$ and $2.7\left(\mathrm{gO}_{2} / \mathrm{m}^{2}\right) / \mathrm{d}$ at RM 86.5

The gross productivity estimated at RM 7.0 in the deep Tidal Reach was $1.7\left(\mathrm{gO}_{2} / \mathrm{m}^{2}\right) / \mathrm{d}$. This smaller value suggests that primary production in the Willamette occurs at higher rates where periphyton predominate. This result agrees with the nature of numerous DO curves obtained at sites throughout the Willamette River. (See Hines and others, 1977). All curves from the shallow Upstream Reach showed considerably larger day-to-night DO fluctuations than those from the Newberg Pool and the Tidal Reach.

Although differences in sampling dates and locations preclude direct comparison, the gross productivities determined by the oxygen-curve method are similar to those obtained by the lightand dark-bottle method.

\section{COMPARISON WITH OTHER RIVERS}

Dvihally (1974) has compiled data on the rates of gross primary productivity in rivers. Her information, compared with the present $\Sigma^{t}$,udy (table 3 ), suggests that primary productivity in the Willamette is low to moderate for a river.

\section{EFFECT OF NUTRIENT ADDITIONS}

The bioassay results (figs. 23, 24, and 25) suggest that nutrient availabilities were not limiting to algal productivity in the lcover Willamette River. In no case did the productivity of treated samples exceed that in control samples. In fact, certain additions, such as the trace nutrients and the waste-water effluents, seem to have caused slight reductions in productivity (figs. 24 and 25).

\section{DISCUSSION}

In the section entitled "Descriptive Assessment," five hypotheses were listed as to why nuisance algal growths have not occurred ir the Willamette River. The remainder of this paper will

TABLE 3.-Estimated gross primary productivity at the surface of different rivers

[ $\left(\mathrm{gO}_{2} / \mathrm{m}^{2}\right) / \mathrm{d}$ corrected for average depth (after Dvihally, 1974)]

\begin{tabular}{|c|c|c|}
\hline River & $\begin{array}{l}\text { Minimum- } \\
\text { maximum }\end{array}$ & Average \\
\hline Raritan (N.J. U.S.A.) & $2.5-25.1$ & $4.7-11.6$ \\
\hline Klyazma (U.S.S.R.) & - & 2.4 \\
\hline Volga at Saratov (U.S.S.R.) & & 1.01 \\
\hline Orinoco (Venezuela) & & .20 \\
\hline Wisla estuary (Poland) & & 5.27 \\
\hline Mosel (dammed) (Germany) & & $20-30$ \\
\hline Ivel (Great Britain) - & $3.2-17.6$ & -- \\
\hline Silver Springs (Fla., U.S.A.) & $8-35$ & $24-57$ \\
\hline $\begin{array}{l}\text { White River (Ind., U.S.A.) } \\
\text { Itchen River (Great Britain) }\end{array}$ & & $.24-57$ \\
\hline $\begin{array}{l}\text { Itchen River (Great Britain) } \\
\text { River Lark (Great Britain) }\end{array}$ & $.4-14.0$ & - \\
\hline $\begin{array}{l}\text { River Lark (Great Britain) } \\
\text { German Danube }\end{array}$ & $\begin{array}{l}.5-39 \\
5-7\end{array}$ & \\
\hline Hungarian Danube & $1-15$ & --- \\
\hline Willamette & $1.6-4.4$ & \\
\hline
\end{tabular}




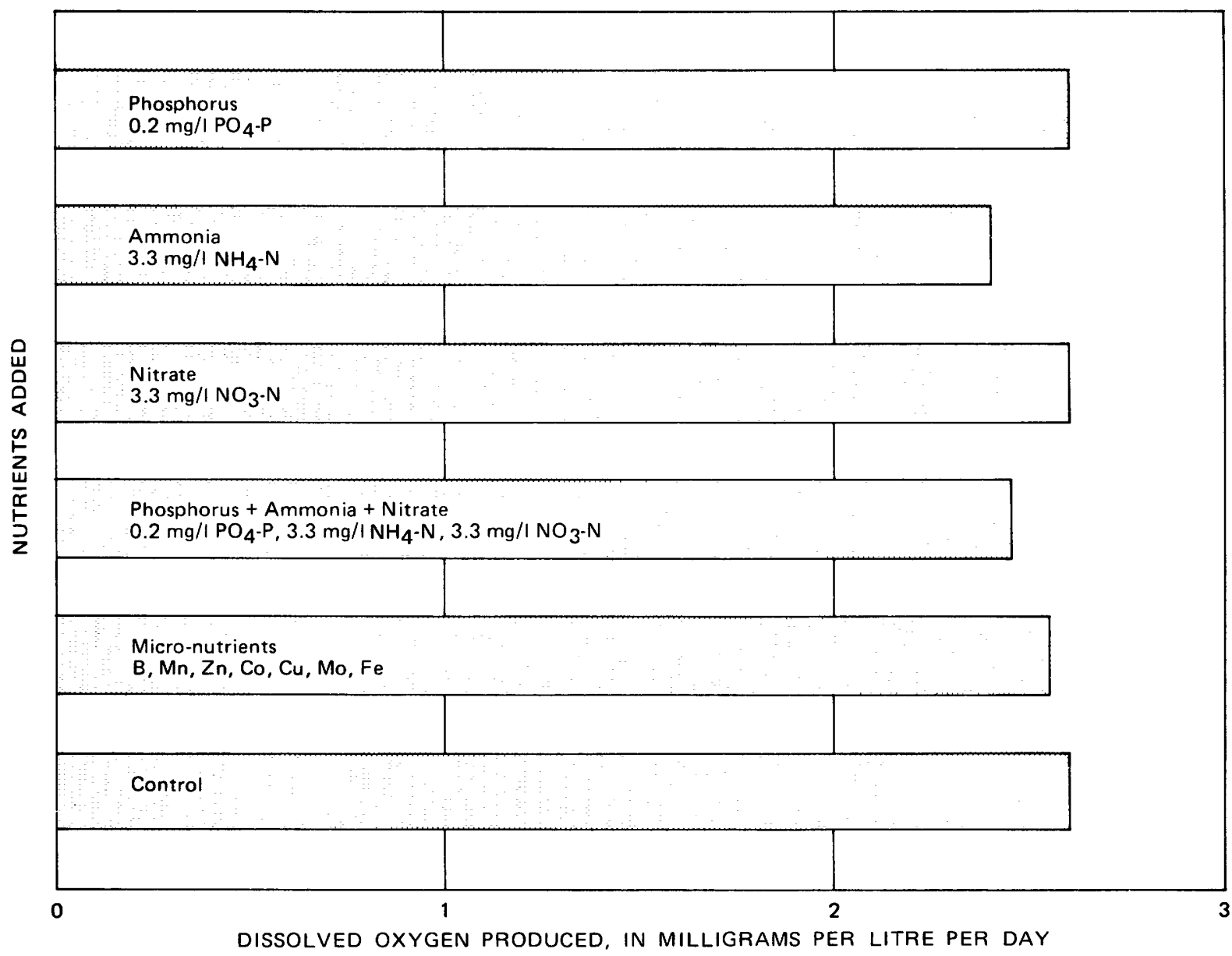

FIGURE 23.-Effect of nutrient additions on algal productivity of Willamette River samples, mile 7.0, ,July $24,1973$.

assess each hypothesis by relating data collected and collated in this study to published findings on river and lake limnology.

\section{LOW-TEMPERATURE LIMITATION}

Water temperatures in the Willamette River reflect the moderate air temperatures of the basin and usually peak in August at about $25^{\circ} \mathrm{C}$. (See fig. 7.) The recorded temperatures are lower than those observed in many lakes and rivers that experience nuisance algal growths. Cairns (1956) noted that diatoms generally are favored at temperatures below $25^{\circ} \mathrm{C}$, green algae between $30^{\circ}$ to $35^{\circ} \mathrm{C}$, and blue-green algae above $35^{\circ} \mathrm{C}$. Hutchinson (1967) concluded that blue-green algae may dominate in mid-to-late summer because they outcompete other forms by growing faster at low inorganic nutrient levels and at high temperatures. However, in the Willamette River basin, blooms of Anabaena occur under the quiescent conditions in certain headwater reservoirs at water temperatures below $18^{\circ} \mathrm{C}$ (Douglas Larson, Oregon Dept. of Environmental Quality, written commun., 1974).

In spite of this occurrence, the moderate summer temperatures in the lower reackes of the Willamette could well be one factor that helps maintain suspended algal growth in its present desirable state.

\section{LIGHT LIMITATION}

As previously noted, the euphotic zone comprises only a small part of the water column in the Newberg Pool and the Tidal Rearh (fig. 8, table 1). In these reaches, both the water and suspended matter are completely mixed to the bottom (unstratified) in most locations. Consequently, only part of the suspended algae is 


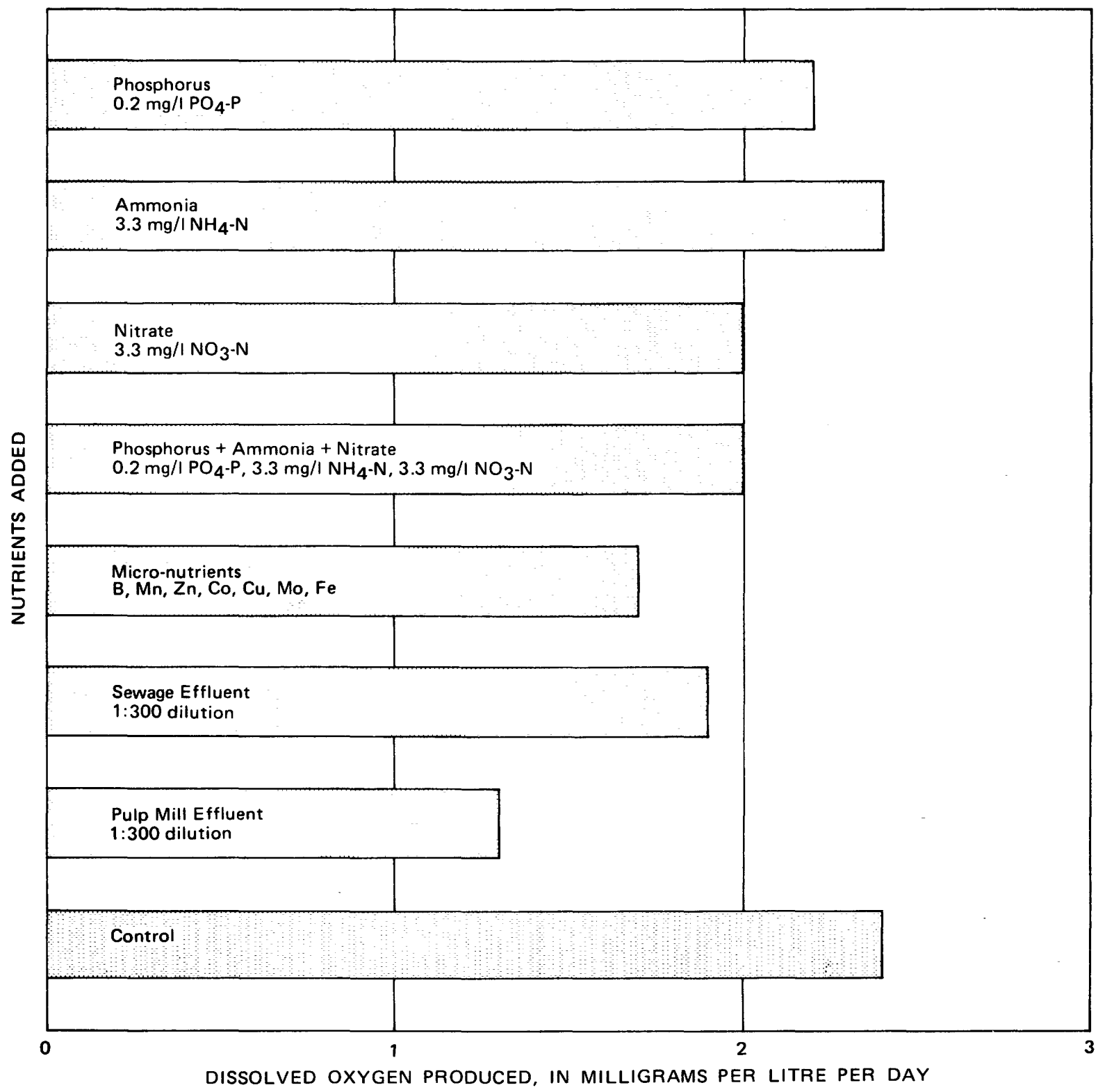

Figure 24.-Effect of nutrient additions on algal productivity of Willamette River samples, mile 12.8, August. 8, 1974 .

capable of photosynthesis at any moment, but algae and all other organisms are respiring throughout the entire water column.

Talling (1971) described the significance of light as a controlling factor in the ecology of freshwater phytoplankton. He pointed out that a high ratio of mixed depth to euphotic depth will act to dilute light income per unit area over a deeper population, until respiration losses exceed photosynthetic gains. The depth at which respiration over the entire mixed layer exceeds oxygen production in the euphotic part of the mixed layer is called the "critical depth" (Sverd"up, 1953). Talling (1971) stated that one case in which critical depth is likely to be exceeded is slowly flowing river water of high light extinction not due to algae.

In the Willamette River, this case appears to apply at RM 7.0. This finding is esfecially significant to the DO regimen of the lower river because the subreach below RM 10 is the primary depositional zone of the Willamette. (See "Tidal 


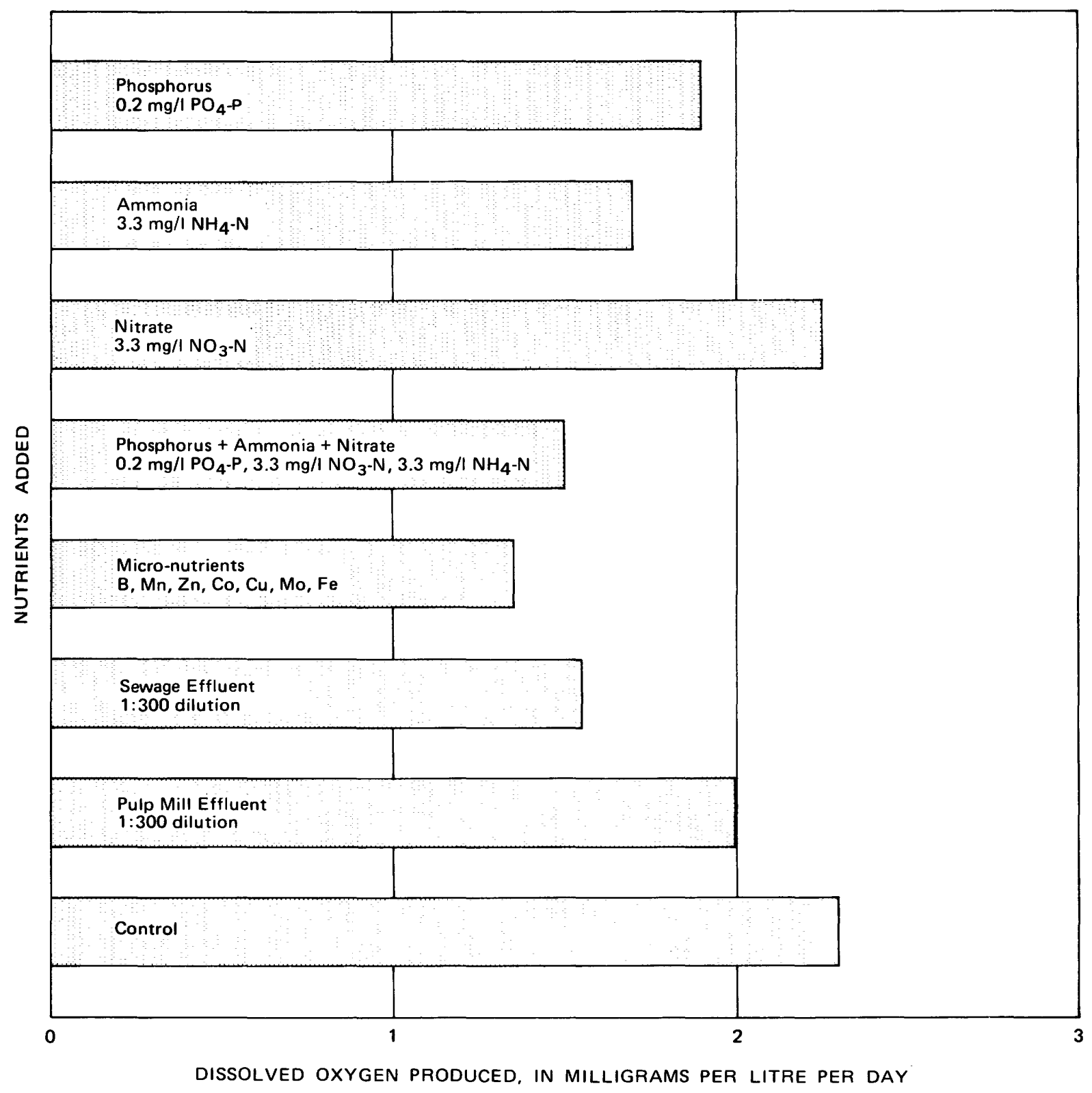

FiguRE 25.-Effect of nutrient additions on algal productivity of Willamette River samples, mile 12.8, Septemb@r $17,1974$.

Reach.") Thus, not only is there the possibility of a critical-depth respiration excess from living algae, but there is the distinct probability that dead algal cells and other organic particles deposit in this zone and thereafter create an oxygen demand (Rickert and others, 1975b; Hines and others, 1977).

Results of the light- and dark-bottle tests lend further support to the possibility of light limitation in the lower Willamette. As shown in figure
22 , gross productivity falls off rapidly with depth and is nil below $10 \mathrm{ft}(3 \mathrm{~m})$.

The combined evidence suggests that low light availability restricts primary production in the Tidal Reach and the Newberg Pool. From a management standpoint, there are two important questions concerning the light limitation: (1) what are the natures and sources of the materials causing the high light extinctior and (2) if turbidity were decreased, would the increased 
light availabilities result in greater primary production and possibly cause undesirable shifts in algal populations? Unfortunately, at present, there is insufficient information to answer either question. Until such time that definite answers are available, it may be prudent to assume that measures aimed at decreasing summertime turbidities (if this is indeed possible) might cause undesirable changes in algal-growth dynamics.

\section{TRACE-NUTRIENT LIMITATION}

The bioassay results (figs. 23-25) provide evidence that availability of key trace elements is not a limitation on algal growth and possible development of nuisance algal conditions. Trace nutrients in addition to those tested are necessary for algal growth. However, the Willamette receives secondary effluents from many sewage treatment plants and urban runoff from several large cities along its $187-\mathrm{mi}(301-\mathrm{km})$ course. For example, the slow-moving Tidal Reach receives combined-sewer overflows below RM 17, sewage effluents upstream from RM 18, and urban drainage along its entire length. With so many sources of trace elements and the presence of numerous metals in bottom sediments (Rickert and others, 1976) it seems unlikely that minor nutrient limitation could occur.

\section{MAJOR-NUTRIENT LIMITATION}

\section{CARBON}

The Willamette is a low-alkalinity $(15-25 \mathrm{mg} / \mathrm{l}$ as $\mathrm{CaCO}_{3}$ ) river (U.S. Geological Survey, 1974); so the possibility of a carbon limitation on algal production needs to be considered. In assessing this topic, there are two relevant questions: (1) are carbon concentrations possibly limiting to gross production of phytoplankton and (2) how does the distribution of carbon among the inorganic forms affect the qualitative nature of the phytoplankton?

The first question can be assessed by comparing the ratios of total carbonate carbon to inorganic nitrogen to orthophosphorus in Willamette River water to reported ratios of carbon:nitrogen:phosphorus (C:N:P) in algal protoplasm. During July and August 1974, the C:N:P ratios at RM 7.0 in the Willamette ranged from 185:21:1 to $285: 60: 1$. In contrast, the commonly quoted ratio of these elements in algae is 106:16:1 (Stumm and Mor- gan, 1970; Kramer and others, 1972), and a ratio reported as typical for blue-green algae is 40:7:1 (James and Lee, 1974).

Comparison of the two sets of ratios shows that on a relative basis carbon in the Willamette was more abundant than the phosphorus needed for algal growth and equal to or more abundant than the required nitrogen. These findings suggest that carbon was not limiting to algal production in the lower Willamette River.

The second question can be assessed by examining diel records of $\mathrm{pH}$ values. During July and August of 1973 and 1974, continuous 3-day $\mathrm{pH}$ traces were obtained at RM's 7.0 (depths of 3 and $20 \mathrm{ft}$, or 1 and $6 \mathrm{~m}$ ) and 12.8 (depth of $\check{f t}$, or $1 \mathrm{~m}$ ). During each of six measurement poriods, the maximum daily variation in $\mathrm{pH}$ was from 6.8 to 7.1. Data collected by the Oregon DEQ under its water-quality monitoring program were within the same range. The stability of $\mathrm{pH}$ near neutrality indicates that free carbon dioxide $\left(\mathrm{CO}_{2}\right)$ was not depleted by algal production to the point where extensive bicarbonate carbon was utilized. Such a condition is favorable to maintenance of diatom and green-algae populations. In contrast, blue-green algae tend to dominate under conditions of high $\mathrm{pH}$, because their advantageous uptake kinetics allow them to compete better for bicarbonate $\mathrm{CO}_{2}$ once free $\mathrm{CO}_{2}$ is depleted (King, 1970, 1972; Shapiro, 1973b). In the lower Willamette River, there apparently was a maintenance of sufficient free $\mathrm{CO}_{2}$ to prevent conditions where blue-green algae would have a competitive advantage over diatoms and green algae.

\section{NITROGEN AND PHOSPHORUS}

The concentrations of nitrogen and phosphorus in the lower Willamette River (figs. 3 and 4 ) are higher than those reported as sufficient to cause nuisance algal blooms in lakes (Sawyer, 1954; Schindler, 1971) but lower than concentrations observed in certain rivers and estuaries that have nuisance algal problems (Shane and others, 1971; Jaworski and others, 1972; Clark end others, 1973).

The observed nitrogen and phosphorus concentrations seem sufficient to support higher levels of primary production than those measured in the river. This deduction is supported by tro bioassay tests (figs. 23-25) which indicate that neither nitrogen nor phosphorus was limiting to algal productivity at RM's 7.0 and 12.8 . 
Comparison of N:P ratios in Willamette River water (fig. 4) to the commonly reported ratio for algal tissue (16:1) indicates that nitrogen was relatively more abundant than phosphorus by a wide margin during 1974 . Thus, if algal production were greatly increased and nutrient loading remained constant, phosphorus (not nitrogen or carbon) would probably become the limiting major nutrient. However, the 1973 and 1974 concentrations of phosphorus were far from being depleted to the point where limitation of productivity was even a remote possibility.

Qualitatively, the diatom populations that dominate the Willamette are consistent with the moderately enriched levels of nitrogen and phosphorus. Limnologists are now piecing together several hypotheses that interrelate broad types of algal populations with observed levels of major nutrients (Hutchinson, 1967; Bush and others, 1972; King, 1972; Shapiro, 1973b). In general, the hypotheses suggest that (1) diatoms predominate in low to moderately enriched waters when concentrations of the major nutrients remain high and at about the initially observed ratios, (2) green algae dominate in moderately to greatly enriched waters, again when nutrient concentrations remain high and in proportion, and (3) blue-green algae dominate in enriched waters, but specifically during periods when prior productivity has depleted the concentration of one or more major nutrients. Under the condition of depleted nutrient concentrations, and especially at high temperatures, blue-green algae apparently have a competitive advantage resulting from favorable kinetics of carbon and phosphorus uptake (Shapiro, 1973b) and the ability of certain species to fix atmospheric nitrogen.

\section{DETENTION-TIME LIMITATION}

As in the Willamette, the suspended-algae populations of most rivers in the United States (Williams, 1964, 1972) and throughout the world (Hynes, 1970; Prowse and Talling, 1958; Villegas and de Giner, 1973) are dominated by diatoms. In a study covering more than 50 United States rivers, Williams (1964) found that diatoms comprised about 80 percent of the algal biomass. Hynes (1970) found from a worldwide review that the plankton of large rivers are almost everywhere dominated by diatoms.

Exceptions to the general pattern of diatom dominance do occur, however, and are usually ob- served in parts of river systems having long detention times (slow rates of water exchange). In recent years, blooms of Anacystis, a blue-green alga, have appeared in the slow-moving Anacostia and Upper Potomac River Estuaries near Washington, D.C. (Jaworski and others, 1972). Another example is the White Nile near Khartoum, where Anabaena appears yearly as the dominant alga after the closure of a dam creates a "river lake" (Prowse and Talling, 1958).

Detention time has been noted by several authors as an important factor in algal productivity and succession in lakes and reservcirs. Welch (1968b) suggested that the failure of blue-green algae to develop in Tennessee Valley reservoirs in spite of high nutrient concentrations and productivity might be partly due to the high exchange rates of water. The detention times in main-stem impoundments were too short (several days) for development of species succession leading to blue-green blooms. Dickman (1969) found that the potential of algal production in a Pritish Columbia lake was not realized because of a high rate of water exchange. He also found that the water-exchange rate exerted a selective pressure in determining the species composition of the phytoplankton. In a study of Moses Lake, Wash., Bush, Welch, and Buchanan (1972) found that water-detention time was an important factor in determining the stability of diatom populations. The entire lake was enriched, but diatoms dominated throughout the summer in an arm of the lake having high water-exchange rates, whereas algal succession to green and blue-green populations occurred in arms having longer detention times. Dillon (1975) found in Cameron Lake, Ontario, that high hydraulic-flushing rates diluted high phosphorus loadings to produce a low degree of eutrophy.

In a study on the enriched Duwamish River Estuary, Welch (1968a, 1969) noted that hydrographic conditions, rather than nutrient content, apparently controlled the occurrence of blooms. He concluded that there was probably a minimum of water-retention time and stability kelow which phytoplankton development is limited (Welch, 1968a).

As previously noted, summer low flows in the Willamette River are augmented by reservoir releases to maintain a minimum of $6,000 \mathrm{ft}^{3} / \mathrm{s}$ $\left(170 \mathrm{~m}^{3} / \mathrm{s}\right)$ at Salem. At this discharge, waterdetention times are short, with volumetric dis- 
placement times of 3.9 days for the Newberg Pool and 7.5 days for the Tidal Reach down to RM 5 (point of mixing with the Columbia River). The water at this discharge is confined within welldefined banks (very few sloughs and side channels) and in most locations is mixed to depth. Thus, in the lower Willamette, the total detention time of water during the period having the slowest flow velocities and the highest water temperatures is about 11 days.

In contrast to the Willamette, low-flow detention time in the $35-\mathrm{mi}(56-\mathrm{km})$ Upper Potomac Estuary (freshwater only) would be 50 days at the 60-day, 2-year low flow of about $2,000 \mathrm{ft}^{3} / \mathrm{s}$ $\left(57 \mathrm{~m}^{3} / \mathrm{s}\right)$ (Walker, 1971). Thus, under low-flow conditions, detention time in the freshwater reach of the Potomac Estuary (where algal blooms occur) is four to five times greater than that observed in the Willamette River between RM's 52 and 5.

On the basis of the results and the noted comparisons, we believe that short detention time is the primary reason productivity is low in the Willamette and that diatoms dominate in spite of the high availability of nitrogen and phosphorus. However, based on published results (Fogg, 1965), the 11-day, low-flow detention time seems long enough to permit significant growth of planktonic blue-green algae. Thus, the absence of nuisance blooms in the Willamette apparently results from the influence of detention time (and associated variables such as local velocities and rates of mixing) on other factors which control algal growth. The following section examines several relationships which could be prominent in the Willamette and in many other rivers.

\section{CONCEPTUAL MODEL OF FACTORS CONTROLLING BIOMASS AND THE NATURE OF ALGAE}

Figure 26 schematically portrays the relationship of algal biomass and dominant algal types to water-detention time and light penetration. The schematic is based on observations made in waters of the Willamette system but is presented as a conceptual model to be considered for all river basins.

The schematic was devised to generalize the locations and stream-current conditions under which nuisance algal growths are likely to occur. Nuisance algal conditions include problems of esthetics, DO depletion, and increased water- treatment costs. In this context, the occurrence of nuisance conditions depends on the type and amount of biomass (weight of algal cells per unit volume of water) that can develop and accumulate in the water.

The relationships depicted in figure 26 are based on the assumption that initial nutrient concentrations are identical in all areas of the basin. However, this does not preclude the possibility that nutrient concentrations can be altered by subsequent algal growth. Indeed, alteration of nutrient concentrations is probably a prerequisite for the occurrence of algal succession.

In the diagram, water-detention time increases toward the right and biomass toward the top. The figure body is divided into three hydraulicecological habitats. The habitat at the left is representative of fast-moving shallow rivers in which the photosynthetic zone extends to the bottom. Under such conditions, periphytio diatoms are typically the dominant algal type and both primary production and biomass are high. However, biomass concentrations level at tho extreme left because high flow velocities scour the riverbottom substrate. For the same reason, the biomass in this general hydraulic regime is probably lower than that which can accumulate in sluggish and standing waters (far right of diagram).

The habitat at the center of the scl omatic is typical of moderate-velocity rivers in which average depth is high relative to the penetration of light. This habitat characteristically occurs downstream from the regime at the left of the figure and is commonly the condition found over long reaches of most large rivers. In such waters, the dominant algae are planktonic diatoms. Biomass is relatively low because of lower productivity and the dispersion and transport of cells by the current. A second curve could be drawn in the middle section of figure 26 to represent shallow, moderate-velocity rivers. However, this hydraulic-ecological habitat was not considered separately because it probably is similar to that existing in shallow, high-velocity rivers.

The hydraulic-ecological habitat at the center of figure 26 can also occur in tidal rivers (such as the Willamette Tidal Reach) where net downstream velocities are low, but the waters are well mixed owing to tidally induced currents.

The habitat at the right of the diagram is representative of sluggish and standing waters such 


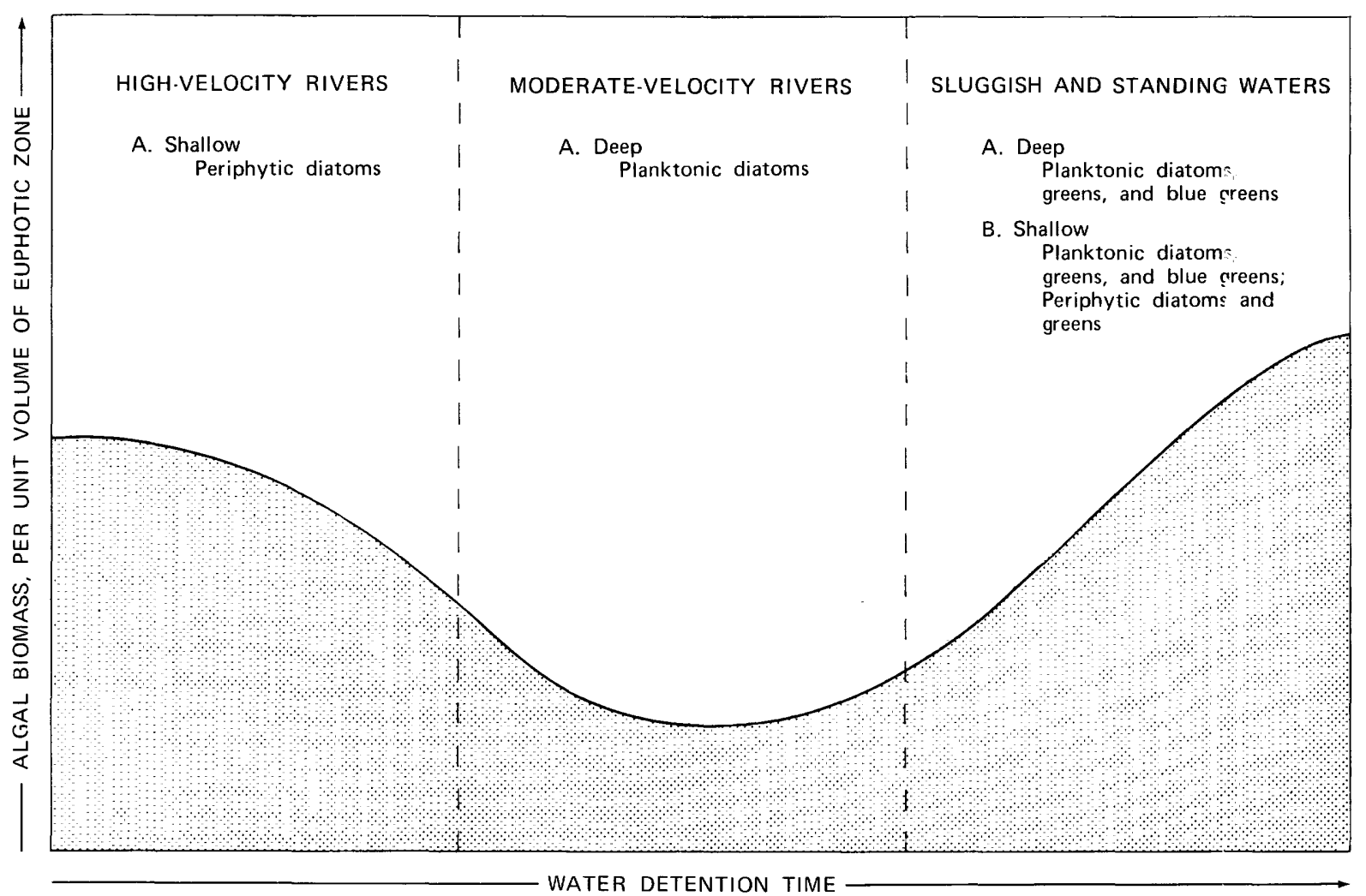

FIGURE 26.-Conceptual diagram relating algal biomass and dominant algal types to water-detention time and light penetration. Shallow implies that the euphotic zone extends to the bottom; deep implies the euphotic z?ne does not reach the bottom.

as pooled rivers, lakes, reservoirs, and poorly mixed estuaries. Primary productivity is often high in the euphotic zones of these waters, and biomass accumulation can be great, leading to nuisance conditions. The deep waters of this hydraulic regime are commonly poorly mixed, or stratified. It is at the surface of such waters that seasonal planktonic blue-green blooms are most likely to occur, sometimes as the result of a seasonal succession beginning with diatoms and green algae.

Productivity and biomass are also high in many sluggish, shallow waters. In rivers having these physical characteristics, the site-to-site environmental conditions tend to be diverse. Consequently, the dominant algal types include a broad spectrum ranging from planktonic diatoms, greens, and blue greens to periphytic diatoms and filamentous greens. Occasionally, periphytic blue-green growths also occur (K. V. Slack, U.S. Geol. Survey, oral commun., 1976). The same broad spectrum of algal types inhakit and can also dominate the shallow areas of lakes, reservoirs, and estuaries.

For either the planktonic or periphytic mode of growth, biomass concentrations generally level at the extreme right of the diagram. This results primarily from exhaustion of available nutrients, but sometimes from self-shading efferts.

Waters in the Willamette River be sin provide examples of most of the hydraulic-ecological habitats delineated in the diagram. The Upstream Reach (figs. 1 and 2; table 1) is an example of a high-velocity shallow river in which the algal population is dominated by periphytic diatoms. The Newberg Pool fits the cetegory of a moderate-velocity deep river dominated by planktonic diatoms, and the Tidal Reach fits into the same category because it is well mixed owing to tidally induced currents.

The Tualatin is a sluggish shallow river in which the dominant algal type varies with loca- 
tion and time, and certain reaches are sometimes dominated by nuisance growths of filamentous greens (McHugh, 1967) and planktonic blue greens (McHugh, 1967; Carter, 1975).

Upstream reservoirs on the Middle Fork Willamette represent a pooled, open-water habitat in which the dominant algal type changes with time of year with blue-green blooms occurring during summer.

Shallow stagnant pools along the banks of the Willamette are another type of habitat implicit in the diagram. During late summer, some of these pools are dominated by profuse growths of filamentous green algae. It is well documented (Hynes, 1970; Whitton, 1975) that different algal assemblages grow in quiet waters along the banks of rivers than in the main current. Indeed, Hynes (1970) believes that most river plankters originate in still or gently flowing waters and subsequently enter rivers where they may or may not reproduce significantly. The combined evidence indicates that green and blue-green algae do grow along the banks of the Willamette and in certain tributaries but do not reproduce significantly after entering the main-stem current.

Two conditions covered in figure 26 but not found in the Willamette River basin are the nuisance algal growths that occur in certain estuaries and along the edges of some lakes and reservoirs. However, many examples of these conditions exist in the United States, and two of the more prominent are the aforementioned blooms of Anacystis in the freshwater Upper Potomac Estuary (Jaworski and others, 1972) and the severe nuisance problems with Cladophora aegogropila in Lake Erie (International Joint Commission, 1969). Cladophora spp. is a filamentous green algae that grows attached to rocky shorelines and shoals in nutrient-enriched waters. Unlike the common nuisance forms of bluegreen algae (for example, Anabaena, Anacystis, Aphanizomenon, Oscillatoria), the periphytic, filamentous green algae seem to be favored by high concentrations of nutrients, especially phosphorus (International Joint Commission, 1969). Also, it is important to note that filamentous green algae apparently are not part of a natural succession to blue-green algae.

With figure 26 for perspective, we can hypothesize why significant growth of blue-green algae does not occur in the Willamette nor in most large rivers (as represented by the middle regime). The exact relationship between waterdetention time, biomass, and the qualitative nature of plankton depends on a large number of factors. Foremost among these are nutrient availability, water temperature, light penetration, and perhaps simply the requirement of some algae for a period of adjustment to new environmental conditions. However, the crux of the conceptual model (fig. 26) is that in free-flowing rivers detention time largely controls these factors in a manner that prevents the onset of conditions conducive to the growth of planktonic blue-green algae.

Perhaps most importantly, flowing water provides a constant chemical influx that prevents depletion of major nutrients to concentrations at which blue-green algae would enjoy a competitive advantage. In addition, most flowing waters remain unstratified (except estuaries), and temperatures do not reach the same levels that would occur in stratified standing water under identical climatic conditions. Moreover, because flowing water carries suspended sediment, rivers are usually more turbid and permit less light penetration than standing water. Also, in flowing water, turbulent mixing negates the buoyancy advantage that blue-green algae enjoy in standing water because of their unique possession of gas vacuoles (Walsby, 1970).

All these factors may be important in various combinations and degrees in different rivers. In the Willamette River, the most important factor is probably the maintenance of a balance in nutrient concentrations by flow and mixing, but low light availability resulting from turkidity also plays a role.

\section{PLANNING IMPLICATION:}

The key to keeping algal growth in the Willamette River at its present balance appears to be control of those factors that maximize summertime flow and thus minimize time of passage. Such control would require maintenance of present levels of flow augmentation and avoidance of large increases in summertime diversions. The high observed concentrations of nitrogen and phosphorus result primarily from point-source loading but, under the present physical conditions, do not stimulate nuisance growths of green and blue-green algae. It appears that treatment to remove nitrogen and phosphorus from point 
sources is not needed to control nuisance algal growths provided summer low flows are maintained in the range of 6,000 to $7,000 \mathrm{ft}^{3} / \mathrm{s}(170$ to $200 \mathrm{~m}^{3} / \mathrm{s}$ ) at Salem. However, future decreases in summer low flows or turbidity levels would cause an increase in the potential for nuisance algal growths; if such decreases are significant, further study will be needed to determine the possible benefits of nutrient removal.

The results of this study indicate that arbitrary standards for permissible nitrogen and phosphorus concentrations in rivers may bear little relationship to primary productivity and to algal-growth dynamics. This means that the need for advanced waste-treatment removal of phosphorus and nitrogen must be assessed on a riverby-river or reach-by-reach basis. The environmental benefits that will result from different pollution-control measures can only be determined by conducting sound river-quality assessments that are keyed to local conditions.

\section{ACKNOWLEDGMENTS}

We wish to acknowledge the aid and encouragement of the Non-Federal Advisory Committee on Water Data for Public Use. Our special thanks go to the members of the Advisory Committee's Ad Hoc Working Group on River Quality Assessment. During the Willamette Study, the group included Howard B. Brown, Robert A. Canham, Edward J. Cleary, Laurence R. Jahn, John E. Kinney, Walter A. Lyon, John A. Roller, and Clarence J. Velz. The authors also acknowledge the helpful suggestions of Glen D. Carter, Lolita M. Carter, Keith V. Slack, Robert C. Averett, and Eugene B. Welch.

\section{GLOSSARY}

[Many definitions were obtained or modified from Slack and others 1 1973 or Britton and others (1975)]

Alga, algae (n), algal (adj). Simple plants, many microscopic, containing chlorophyll. Most algae are aquatic and may produce a nuisance when conditions are suitable for prolific growth and subsequent death and decay.

Algal bloom (n). A large number of a particular algal species, frequently amounting to 0.5 to 1 million cells per litre. Sometimes defined as a readily visible concentrated growth or aggregation of algae.
Aliquot (n, adj). A known exact part of a whole sample.

Aquatic (adj). Pertaining to water; aquatic organisms such as algae or fish live in water.

Benthos (n), benthic (adj). The community of organisms living in or on the bottom of an aquatic environment.

Bioassay (n). The use of living organisms to test the effects of a substance.

Biomass (n). The weight of living matter present in a unit area or volume at a given time.

Blue-green algae (n). A group of algae with a blue pigment in addition to green cl lorophyll. Members of this group often cause nuisance conditions in water.

Compensation depth (n). The depth of water at which oxygen production by photosynthesis balances oxygen uptake by respiration of plants and animals.

Diatom (n). A unicellular or colonial alga having a siliceous shell.

Diel (adj). Relating to a 24-hour period that usually includes a day and the adjoining night.

Diurnal (adj). Relating to daytime or something recurring every day, often used as a synonym for diel.

Dissolved oxygen (n). The oxygen dissolved in water, waste water, or other liquid, usually expressed in milligrams per litre or percent of saturation. Abbreviated DO.

Ecology (n), ecological (adj)! The science or study of the relation of organisms or groups of organisms to their environment.

Enrichment (n). Addition or accumulation of plant nutrients within a body of water.

Euphotic zone (n). That part of the aquatic environment in which the light is sufficient for photosynthesis; commonly considered to be that part of a water body in which the intensity of underwater light equals or exceeds 1 percent of the intensity of surface light.

Eutrophication (n), eutrophic (adj). The natural process of enrichment and aging of a body of water that may be accelersted by the activities of man.

Eutrophic waters (n). Waters with $\varepsilon$ good supply of nutrients. These waters may support rich organic production such as algal blooms.

Genus, genera (n). The taxonomic category below family, consisting of species: the first part of the scientific name of organisms.

Green algae (n). Algae that have pigrents simi- 
lar in color to those of higher green plants. Some forms produce algal mats or floating "moss" in lakes.

Gross primary productivity (n). The total rate at which organic matter is formed by photosynthesis, including the organic matter used up in respiration by plants and animals. The term is synonymous with total photosynthesis.

Growth (n). The increase in biomass by synthesis of living matter.

Habitat (n). The place where an organism lives.

Interpretative (adj). A type of sampling program or study designed to collect information useful in describing a system, and cause and effect relationships within the system.

Limnology (n). The science or study of the physical, chemical, and biological aspects of inland waters.

Loading (n). The amount of a given substance or type of material discharged or otherwise entering a water body in a given unit of time.

Membrane filter (n). A thin, microporous material of specific pore size used to filter bacteria, algae, and other very small particles from water.

Net primary productivity (n). The rate of storage of photosynthetically produced organic matter in plant tissues in excess of the respiratory utilization by plants and animals. The term is synonymous with net photosynthesis.

Nuisance ( $n$, adj). Pertaining to the waterquality conditions caused by algal blooms. Blooms are often esthetically objectionable because they create floating green mats, cause foul odors, and cover beaches and shorelines. Blooms also reduce dissolved-oxygen concentrations in water through the respiration of living cells and the decay of dead cells. Algal cells also can clog the intakes of water-supply systems and interfere with water treatment.

Nutrient (n). Any chemical element, ion, or compound that is required by an organism for the continuation of growth, for reproduction, and for other life processes. Trace nutrients are substances required by an organism in very small amounts.

Organic (n). Pertaining or relating to a compound containing carbon.

Organism (n). Any living entity.

Periphyton (n), periphytic (adj). The community of micro-organisms that is attached to or lives upon submerged surfaces.
pH (n). The reciprocal of the logarithm of the hydrogen-ion concentration. The $\mathrm{pH}$ value of water is a measure of the degree of its acid or alkaline reaction.

Photosynthesis (n), photosynthetic (adj). The process by which simple sugars and starches are produced from carbon dioxide and water by living plant cells, with the aid of chlorophyll and in the presence of light. In the process, carbon dioxide is consumed and oxygen is released.

Phytoplankter (n). An individual phytoplanktonic organism.

Phytoplankton (n), phytoplanktonic (adj). The plant part of the plankton.

Plankton (n), planktonic (adj). The community of suspended or floating organisms that drifts passively with water currents. The organisms are mostly microscopic and include both plants and animals.

Primary production (n). The weight of new organic material created by photosynthesis, or the energy it represents.

Primary productivity (n). The rate of primary production, expressed as grams of organic matter per metre squared per day.

Reconnaissance ( $n$, adj). A type of sample or sampling program designed to determine the present status of something; a preliminary survey.

Respiration (n). A life process in which carbon compounds are oxidized to carbon dioxide and water. The liberated energy is used in the metabolic processes of living organisms.

Sediment (n). Fragmental material, both mineral and organic, that is in suspension or is being transported by the water mass or has been deposited on the bottom of the aquatic environment.

Sedimentation (n). The deposition of suspended material by water, wind, or gravity transport.

Species (n, sing. and pl.). The basic unit for the classification of organisms; the taxonomic category below genus, and the second part of the scientific name of an organism.

Substrate (n). The physical surface upon which something lives.

Suspended sediment (n). Fragmental material, both mineral and organic, that is maintained in suspension in water.

Turbidity (n), turbid (adj). The ability of materials suspended in water to reduce the penetration of light. 


\section{REFERENCES CITED}

American Public Health Association and others, 1971, Standard methods for the examination of water and wastewater [13th ed.]: New York, Am. Public Health Assoc., 874 p.

Britton, L. J., Averett, R. C., and Ferreira, R. F., 1975, An introduction to the processes, problems, and management of urban lakes: U.S. Geol. Survey Circ. 601-K, 22 p.

Brown, Eugene, Skougstad, M. W., and Fishman, M. J., 1970, Methods for collection and analysis of water samples for dissolved minerals and gases: U.S. Geol. Survey Tech. Water Resources Inv., book 5, chap. Al, 160 p.

Bush, R. M., Welch, E. B., and Buchanan, R. J., 1972, Plankton associations and related factors in a hypereutrophic lake: Water, Air, and Soil Pollution, v. 1, no. 3, p. 257-274.

Cairns, John, Jr., 1956, Effects of increased temperatures on aquatic organisms: Industrial Wastes, v. 1, no. 4, p. 150-152.

Carter, L. M., 1975, The effect of human activity on the middle course of the Tualatin River, Oregon: Ph.D. thesis submitted to the Graduate School of Portland State Univ., Portland, Oreg., 166 p.

Clark, L. J., Donnelly, D. K., and Villa, Orterio, Jr., 1973, Nutrient enrichment and control requirements in the upper Chesapeake Bay: Environmental Protection Agency, Summary and conclusions from Chesapeake Tech. Support Lab. Rept. 56, 88 p.

Deffeyes, K. S., 1965, Carbonate equilibria: A graphic and algebraic approach: Limnology and Oceanography, v. 10, no. 3, p. 412-426.

Dickman, Mike, 1969, Some effects of lake renewal on phytoplankton productivity and species composition: Limnology and Oceanography, v. 14, no. 5, p. 660-666.

Dillon, P. J., 1975, The phosphorus budget of Cameron Lake, Ontario: The importance of flushing rate to the degree of eutrophy of lakes: Limnology and Oceanography, v. 20, no. 1, p. 28-39.

Dvihally, S. T., 1974, Estimation of the primary productivity of the Hungarian section of the River Danube: Annales Univ. Sci. Budapest, v. 13, p. 33-43.

Environmental Protection Agency, 1971, Algal assay procedure: Bottle test: Natl. Eutrophication Research Program rept., $82 \mathrm{p}$.

Fogg, G. E., 1965, Algal cultures and phytoplankton ecology: Madison, Wisconsin Univ. Press, 126 p.

Gleeson, G. W., 1972, The return of a river, the Willamette River, Oregon: Advisory Comm. on Environmental Sci. and Technology and Water Resources Inst., Corvallis, Oregon State Univ., 103 p.

Golterman, H. L., and Clymo, R. S., eds., 1971, Methods for chemical analysis of fresh waters [revised]: Internat. Biol. Programme Handb. 8, Oxford and Edinburgh, Blackwell Sci. Pub., 180 p.

Harris, D. D., 1968, Travel rates of water for selected streams in the Willamette River basin, Oregon: U.S. Geol. Survey Hydrol. Inv. Atlas HA-273.

Hartigan, J. A., 1975, Clustering algorithms: New York, John Wiley \& Sons, Inc., 351 p.

Hines, W. G., McKenzie, S. W., Rickert, D. A., and Rinella, F. A., 1977, Dissolved oxygen regimen of the Willamette River, Oregon, under conditions of basinwide secondary treatment: U.S. Geol. Survey Circ. 715-I (in press).
Huber-Pestalozzi, G., 1942, Das phytoplankton c'es Susswassers, pt. 2 in August Thienemann, ed., Die Binnengewasser, vol. 16: Stuttgart, Schweizerbart'sche, p 367-549.

Hustedt, Friedrich, 1930, Bacillariophyta, in A. Pascher, ed., Die Susswasser-flora Mitteleuropas, vol. 10: Jena, Gustav, Fischer, 466 p.

Hutchinson, G. E., 1967, Introduction to lake bio'ngy and the limnoplankton, vol. II of A treatise on limnology: New York, John Wiley \& Sons, Inc., 1115 p.

Hynes, H. B. H., 1970, Ecology of running water: Toronto Univ. Press, 555 p.

International Joint Commission, 1969, Pollution of Lake Erie, Lake Ontario, and the International section of the St. Lawrence River, vol. 2: Washington, D.C., 316 p.

James, D. H., and Lee, G. F., 1974, A model of irorganic carbon limitation in natural waters: Water, $A$ ir, and Soil Pollution, v. 3, p. 315-320.

Jaworski, N. A., and Hetling, L. J., 1970, Relative contributions of nutrients to the Potomac River basin from various sources: Federal Water Pollution Control Admin., Chesapeake Tech. Support Lab. Rept. 31, 36 p.

Jaworski, N. A., Lear, D. W., Jr., Villa, Orterin, Jr., 1972, Nutrient management in the Potomac estuary, in G. E. Likens, ed., Proceedings of the symposium on nutrients and eutrophication: The limiting-nutrient controversy: Am. Soc. Limnology and Oceanography, $328 \mathrm{p}$.

Kilham, Peter, 1971, A hypothesis concerning silica and the freshwater planktonic diatoms: Limnology and Oceanography, v. 16 , no. 1 , p. 10-18.

King, D. L., 1970, The role of carbon in eutrophication: Water Pollution Control Federation Jour., v. 42, no. 11, p. 2035-2051.

1972, Carbon limitation in sewage lagoons, in G. E. Likens, ed., Proceedings of the symposium on nutrients and eutrophication: The limiting-nutrient controversy: Am. Soc. Limnology and Oceanography, 328 p.

Kramer, J. R., Herbes, S. E., and Allen, H. E., 1972, Phosphorus: Analysis of water, biomass, and sediment, in Allen, H. E., and Kramer, J. R., eds., Nutrients in natural waters: New York, Wiley-Interscience, $457 \mathrm{~F}$.

McGauhey, P. H., 1974, Synopsis of workshop on modeling the eutrophication process, in E. J. Middlebrooks, D. H. Falkenborg, and T. E. Maloney, eds., Modeling the eutrophication process: Ann Arbor Sci., 228 p.

McHugh, R. A., 1967, Tualatin River water quality control needs: Oregon State Sanitary Authority rept., $113 \mathrm{p}$.

Palmer, C. M., 1969, A composite rating of alge tolerating organic pollution: Jour. Phycology, v. 5, no. 1, p. 78-82.

Patrick, Ruth, and Reimer, C. W., 1966, The diatoms of the United States, vol. 1: Acad. Natural Sci., F'iiladelphia, $688 \mathrm{p}$.

Prowse, G. A., and Talling, J. F., 1958, The seasonal growth and succession of plankton algae in the White Nile: Limnology and Oceanography, v. 3, no. 2, p. 222-238.

Rickert, D. A., Hines, W. G., and McKenzie, S. W., 1975a, Methods and data requirements for river-quality assessment: Water Resources Bull., v. 11, no. 5, p. 1013-1039. $-1975 \mathrm{~b}$, Planning implications of dissolved-oxygen depletion in the Willamette River, Oregon, in William Whipple, Jr., ed., Urbanization and water-quality control: Minneapolis, Am. Water Resources Assoc., F. 70-84.

Rickert, D. A., Kennedy, V. C., McKenzie, S. W., and Hines, W. G., 1976, A synoptic survey of trace metrls in bottom 
sediments of the Willamette River, Oregon: U.S. Geol. Survey Circ. 715-F, 27 p.

Sawyer, C. N., 1954, Factors involved in disposal of sewage effluents to lakes: Sewage and Industrial Wastes, v. 26, no. 3 , p. 317-325.

Schindler, D. W., 1971, Carbon, nitrogen, and phosphorus and the eutrophication of freshwater lakes: Jour. Phycology, v. 7 , no. 4 , p. 321-329.

Shane, M. S., DeMichele, E., and Cannon, R., 1971, Water quality and plankton ecology - the Christina River, Delaware: Environmental Pollution, v. 2, p. 81-95.

Shapiro, Joseph, 1973a, A field fixation technique for dissolved phosphate in lake water: Limnology and Oceanography, v. 18 , no. 1 , p. 143-145.

1973b, Bluegreen algae: Why they become dominant: Sci., v. 179 , no. 4071 , p. $382-384$.

Slack, K. V., Averett, R. C., Greeson, P.E., and Lipscomb, R. G., 1973, Methods for collection and analysis of aquatic biological and microbiological samples: U.S. Geol. Survey Tech. Water-Resources Inv., book 5, chap. A4, 165 p.

Stumm, Werner, and Morgan, J. J., 1970, Aquatic chemistry: New York, Wiley-Interscience, 583 p.

Sverdrup, H. W., 1953, On conditions for the vernal blooming of diatoms: Conseil. Permanent Internat. Explor. Mer. Jour., v. 18, p. 287-295.

Talling, J. F., 1960, Self-shading effects in natural populations of a planctonic diatom: Wetter Leben, v. 12, p. 235242.

1971, The underwater light climate as a controlling factor in the production ecology of freshwater phytoplankton: Internat. Verein. Limnologie Mitt., v. 19, p. 214-243.

U.S. Geological Survey, 1974, Water quality records, pt. 2 of Water resources data for Oregon: Portland, Oreg., Water Resources Div., U.S. Geol. Survey, 146 p.

U.S. Public Health Service, 1964, Water pollution surveillance system: Ann. compilation of data for October 1, 1962-September 30, 1963, v. 10, 179 p.

Velz, C. J., 1961, Supplementary report on lower Willamette River waste assimilation capacity: Natl. Council for Stream Improvement of Pulp, Paper, and Paperboard In- dustries, Inc., School of Public Health, Michigan Univ., $28 \mathrm{p}$.

Villegas, Iraides, and de Giner, Griselda, 1973, Phytoplankton as a biological indicator of water quality: Water Resources Bull., v. 7, no. 3, p. 479-487.

Vollenweider, R. A., ed., 1969, A manual on methods for measuring primary production in aquatic environments: Internat. Biol. Programme Handb. 12, Oxford and Edinburgh, Blackwell Sci. Pub., 213 p.

Walker, P. N., 1971, Flow characteristics of Maryland streams: Maryland Geol. Survey Rept. Inv. 16, 160 p.

Walsby, A. E., 1970, The nuisance algae: Curiosities in the biology of planktonic blue-green algae: Proc. Soc. Water Treatment Exam., v. 19, no. 4, p. 359-373.

Weber, C. I., 1971, A guide to the common diatoms at water pollution surveillance system stations: Environmental Protection Agency, Rept. Natl. Environmental Research Center, Cincinnati, 101 p.

Welch, E. B., 1968a, Phytoplankton and related water quality conditions in an enriched estuary: Water Pollution Control Federation Jour., v. 40, no. 10, p. 1711-1727.

$-1968 \mathrm{~b}$, Existing and potential problems of excessive eutrophication in the Tennessee Valley: Proc. 7th Ann. Sanitary and Water Resources Eng. Conf., Vanderbilt Univ., p. 45-73.

1969, Factors initiating phytoplankton klooms and resulting effects on dissolved oxygen in Duwamish River estuary, Seattle, Washington: U.S. Geol. S rrvey WaterSupply Paper 1873-A, 62 p.

Whitton, B. A., 1975, Algae, in Whitton, B. A., ed., River ecology: Berkeley, California Univ. Press, 725 p.

Willamette Basin Task Force, 1969, The Willamette Basin comprehensive study of water and related land resources, Appendix B, Hydrology: Pacific Northwest River Basins Comm. rept. $163 \mathrm{p}$.

Williams, L. G., 1964, Possible relationships between plankton-diatoms species numbers and water-quality estimates: Ecology, v. 45, no. 4, p. 809-823.

1972, Plankton diatom species biomass and the quality of American rivers and the Great Lakes: Ecology, v. 53, no. 6 , p. 1038-1050. 
TABLES 4 AND 5 
TABLE 4.-Algal counts at mile 7.0, Willamette River, Oreg., during 1973

[Counts, in number per millilitre]

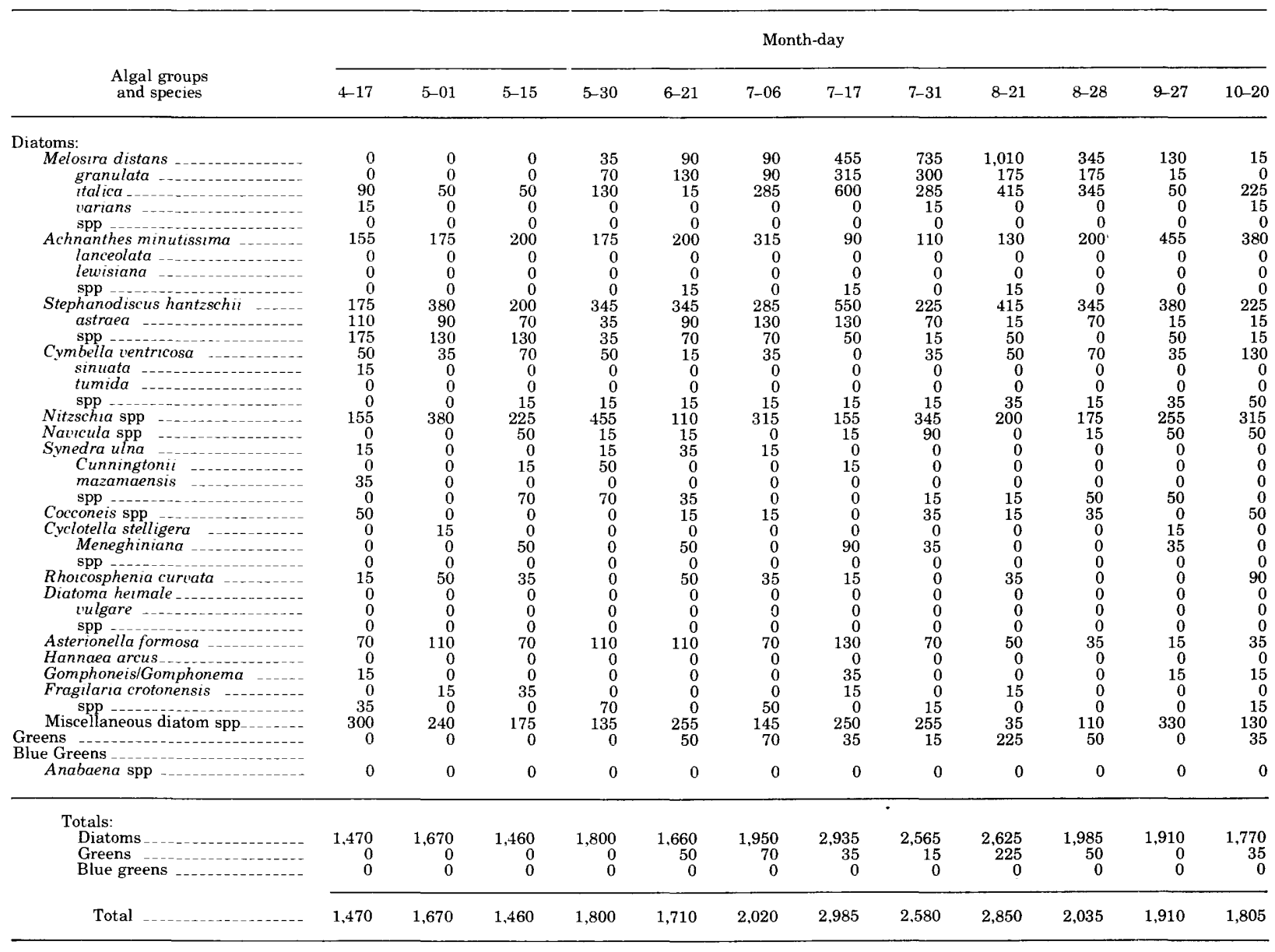


TABLE 5.-Algal counts at mile 7.0, Willamette River, Oreg., during 1974 [Counts, in number per millilitre]

\begin{tabular}{|c|c|c|c|c|c|c|c|c|}
\hline \multirow[b]{2}{*}{$\begin{array}{l}\text { Algal groups } \\
\text { and species }\end{array}$} & \multicolumn{8}{|c|}{ Month-day } \\
\hline & $6-12$ & $6-25$ & $7-09$ & $7-22$ & $8-07$ & $8-20$ & $9-04$ & $9-18$ \\
\hline \multicolumn{9}{|l|}{ Diatoms: } \\
\hline Melosira distans & 0 & 35 & 50 & 15 & 315 & 735 & 255 & 200 \\
\hline granulata & 0 & 0 & 0 & 35 & 15 & 70 & 70 & 345 \\
\hline italica & 0 & 50 & 90 & 70 & 35 & 15 & 155 & 90 \\
\hline varians & 0 & 0 & 0 & 0 & 0 & 0 & 0 & 0 \\
\hline spp & 0 & 0 & 0 & 0 & 0 & 0 & 0 & 0 \\
\hline Achnanthes minutissima & 90 & 50 & 90 & 175 & 130 & 175 & 315 & 315 \\
\hline lanceolata & 0 & 0 & 0 & 0 & 0 & 0 & 0 & 0 \\
\hline lewisiana & 0 & 0 & 0 & 0 & 0 & 0 & 0 & 0 \\
\hline spp & 0 & 0 & 0 & 70 & 0 & 35 & 50 & 15 \\
\hline Stephanodiscus hantzschii & 155 & 285 & 805 & 660 & 805 & 660 & 805 & 805 \\
\hline astraea & 70 & 200 & 315 & 380 & 35 & 175 & 110 & 455 \\
\hline spp & 0 & 70 & 50 & 70 & 90 & 70 & 50 & 70 \\
\hline Cymbella ventricosa & 50 & 15 & 35 & 0 & 0 & 35 & 35 & 50 \\
\hline sinuata & 15 & 15 & 0 & 0 & 0 & 0 & 35 & 0 \\
\hline tumida & 0 & 0 & 0 & 0 & 0 & 0 & 0 & 0 \\
\hline spp & 70 & 35 & 50 & 70 & 35 & 70 & 35 & 70 \\
\hline Nitzschia spp & 735 & 285 & 315 & 175 & 200 & 315 & 415 & 380 \\
\hline Navicula spp & 50 & 70 & 50 & 110 & 15 & 50 & 90 & 0 \\
\hline Synedra ulna & 15 & 15 & 0 & 15 & 0 & 50 & 35 & 35 \\
\hline Cunningtonii & 15 & 90 & 0 & 0 & 15 & 0 & 0 & 15 \\
\hline mazamaensis & 0 & 0 & 0 & 0 & 0 & 0 & 0 & 0 \\
\hline spp & 0 & 0 & 0 & 0 & 0 & 0 & 0 & 0 \\
\hline Cocconeis spp & 0 & 0 & 35 & 0 & 0 & 15 & 15 & 35 \\
\hline Cyclotella stelligera & 0 & 0 & 15 & 50 & 15 & 35 & 50 & 70 \\
\hline Meneghiniana & 0 & 0 & 50 & 0 & 35 & 70 & 110 & 15 \\
\hline spp & 0 & 0 & 0 & 15 & 0 & 35 & 35 & 0 \\
\hline Rhoicosphenia curvata & 0 & 0 & 0 & 0 & 0 & 0 & 15 & 0 \\
\hline Diatoma heimale & 0 & 0 & 0 & 0 & 0 & 0 & 0 & 0 \\
\hline vulgare & 0 & 0 & 0 & 0 & 0 & 0 & 0 & 0 \\
\hline spp & 0 & 0 & 0 & 0 & 0 & 0 & 0 & 0 \\
\hline Asterionella formosa & 15 & 50 & 110 & 50 & 50 & 35 & 15 & 50 \\
\hline Hannaea arcus & 0 & 0 & 0 & 0 & 0 & 0 & 0 & 0 \\
\hline Gomphoneis/Gomphonema & 50 & 0 & 50 & 30 & 0 & 0 & 15 & 50 \\
\hline Fragilaria crotonensis & 70 & 15 & 50 & 0 & 15 & 0 & 0 & 15 \\
\hline spp & 35 & 0 & 0 & 15 & 0 & 0 & 0 & 0 \\
\hline \multirow{2}{*}{\multicolumn{9}{|c|}{ Greens: }} \\
\hline & & & & & & & & \\
\hline Scenedesmus & 0 & 0 & 0 & 15 & 0 & 0 & 0 & 0 \\
\hline Pediastrum & 0 & 0 & 0 & 0 & 0 & 0 & 0 & 0 \\
\hline Single cell & 0 & 0 & 0 & 0 & 0 & 90 & 15 & 0 \\
\hline Colonial & 15 & 15 & 35 & 50 & 50 & 15 & 130 & 15 \\
\hline Filamentous & 0 & 0 & 0 & 0 & 0 & 15 & 0 & 0 \\
\hline \multicolumn{9}{|l|}{ Blue greens: } \\
\hline Anabaena spp & 15 & 0 & 50 & 35 & 35 & 50 & 0 & 15 \\
\hline \multicolumn{9}{|l|}{ Totals } \\
\hline Diatoms & 1,605 & 1,315 & 2,215 & 2,065 & 1,820 & 2,650 & 2,945 & 3,110 \\
\hline Greens & 15 & 15 & 35 & 65 & 50 & 120 & 145 & 15 \\
\hline Blue greens & 15 & 0 & 50 & 35 & 35 & 50 & 0 & 15 \\
\hline Total & 1,635 & 1,330 & 2,300 & 2,165 & 1,905 & 2,820 & 2,890 & 3,140 \\
\hline
\end{tabular}


